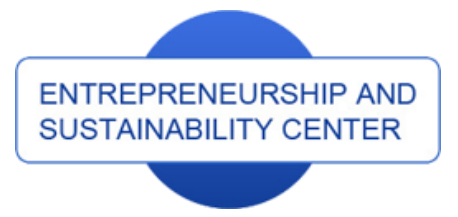

Publisher

http://jssidoi.org/esc/home enterprise

europe

network

Business Support on Your Doorstep

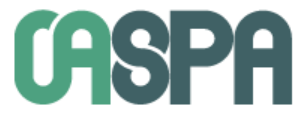

Scopus Web of Science $^{2}$

\title{
INFLUENCE OF EXISTING SOCIAL AND ECONOMIC INTERACTIONS ON SUSTAINABLE TERRITORY DEVELOPMENT: THE CASE OF ICELAND*
}

\author{
Vera Komarova ${ }^{1}$, Jelena Lonska ${ }^{2}$, Olga Lavrinenko $^{3}$, Vladimir Menshikov ${ }^{4}$ \\ 1,3,4 Institute of Humanities and Social Sciences, Daugavpils University, Parades Str. 1-421, Daugavpils, LV-5401, Latvia \\ ${ }^{2}$ Business and Society Process Research Center, Rezekne Academy of Technologies, Atbrivosanas alley 115, Rezekne, \\ LV-4601, Latvia \\ E-mails: ${ }^{1}$ veraboronenko@inbox.lv; ${ }^{2}$ jelena.lonska@rta.lv; ${ }^{3}$ olga.lavrinenko@du.lv; ${ }^{4}$ vladimirs.mensikovs@du.lv
}

Received 16 March 2017; accepted 20 November 2017; published 30 March 2018

\begin{abstract}
Iceland was identified as a typical country with relatively high achieved competitiveness level and at the same time negative growth capacity - so, with eroded sustainability of territory development. As a research hypothesis the authors suggest that Iceland's social and economic interactions with other "worlds-economies" are not diversified enough. The analysis of export/import and international migration flows of Iceland shows that a market-capitalist "world-economy" is an absolute leader (80-90 \%) for Icelandic international trade and migration. Analysis of air logistical interconnections shows that a kind of sub-"world-economy" is formed which can be referred to as a Northern-Atlantic one. As results of regression analysis show social and economic interactions with the representatives of its own "world-
\end{abstract}

\footnotetext{
* The research leading to these results has received funding from the European Union Seventh Framework Programme (FP7 2007-2013) under grant agreement No. 291823 Marie Curie FP7-PEOPLE-2011-COFUND (The new International Fellowship Mobility Programme for Experienced Researchers in Croatia - NEWFELPRO). This article has been worked out as a part of the project „Rethinking Territory Development in Global Comparative Researches (Rethink Development)” which has received funding through NEWFELPRO project under grant agreement No. 10
}
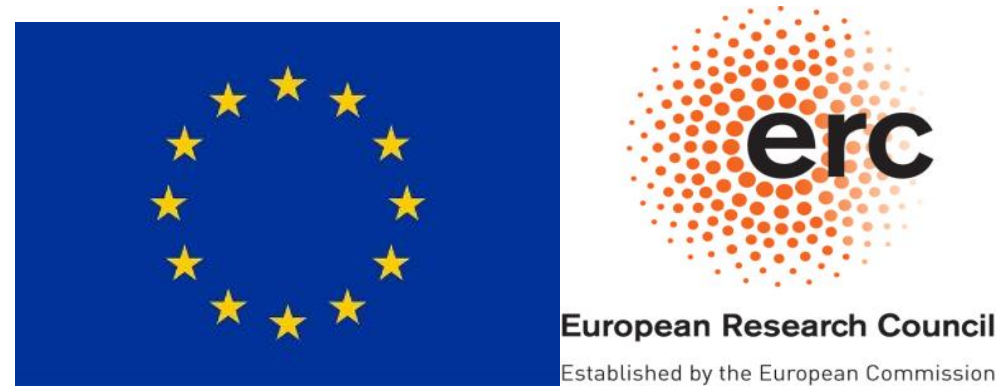


\section{The International Journal}

The International Journal
STAINABILITY ISSUES

ISSN 2345-0282 (online) http://jssidoi.org/jesi/

2018 Volume 5 Number 3 (March)

http://doi.org/10.9770/jesi.2018.5.3(1)

economy" mainly draw Iceland's sustainable territory development in their direction, and, as the trends of their development are negative or stagnate (USA and Spain), Iceland's trend of sustainable territory development is also drawn after them. In its turn, rather infrequent social and economic interactions with other "worlds-economies" either do not influence significantly Iceland's sustainable territory development (as interactions with Brazil do) or influence in the opposite way (as interactions with China do). Therefore, the practical efficiency of recommendation of Human Development Report 2013 to interact more actively with other "worlds-economies" is not so far proved in social and economic reality - at least, in the case with Iceland as a typical highly-developed capitalist country.

Keywords: sustainable territory development, spatial economics, social and economic interactions, Iceland, "worlds-economies"

Reference to this paper should be made as follows: Komarova, V.; Lonska, J.; Lavrinenko, O.; Menshikov, V. 2018. Influence of existing social and economic interactions on sustainable territory development: the case of Iceland, Entrepreneurship and Sustainability Issues 5(3): 412- 437. https://doi.org/10.9770/jesi.2017.5.3(1)

JEL Classifications: O11, O18, R58

\section{Introduction}

The authors have chosen Iceland for the research of sustainable development of its territory and the role of social and economic interactions in this process. Why Iceland? Within the research project "Rethinking Territory Development in Global Comparative Researches (Rethink Development" (2014-2016) managed by one of the authors, which was realized at the Faculty of Economics of the University of Rijeka (Croatia), Iceland was identified as a country with a relatively high achieved level of sustainable territory development (empirically measured by the Global Competitiveness Index (GCI) created by the World Economic Forum), and at the same time negative growth capacity, i.e. a trend of relatively fast declining of its level of sustainable territory development.

The average annual change of the GCI of Iceland for the period 2005-2014 is -0.06 points on the scale from 1 to 7, and this decline is one of the highest in the world. According to the data of the Global Competitiveness Reports published by the World Economic Forum, in 2005 Iceland had 5.34 points of the GCI on the scale from 1 to 7 (Lopez-Claros et al., 2005), in 2006 - 5.40 points (Lopez-Claros, 2006), in 2007 - 5.02 points (Lopez-Claros and Schwab, 2007), in 2008 - 5.05 points (Schwab, 2008), in $2009-4.80$ points (Schwab, 2009), in $2010-4.68$ points (Schwab, 2010), in 2011 - 4.75 points (Schwab, 2011), in 2012 - 4.74 points (Schwab, 2012), in 2013 4.66 points (Schwab, 2013), in $2014-4.71$ points (Schwab, 2014), in $2015-4.83$ points (Schwab, 2015) (see Figure 1).

This general trend of dramatic decrease level of sustainable territory development of a highly-developed country generates a certain interest and requires explanations by means of searching for and analyzing those factors which promote this kind of recession in sustainable territory development or - vice versa- accelerate it. Within the framework of this research, the emphasis will be put on the role of social and economic interactions in sustainable territory development of Iceland. Why this kind of emphasis? Because the present research will be carried out within the theoretical framework of classical spatial economics, which suggests that the state of sustainable territory development of a country depends not only on its own capacity but also on development of territories which are included in social and economic interactions of this country (within the framework of another approach of the spatial economics - depends on development of territories, which are located around the analyzed country) (Kuenne, 1963; Takayama and Judge, 1964; Anselin, 1988, 2003; LeSage, 1999; Fotheringham et al., 2000; LeSage and Pace, 2009; Elhorst, 2014; Tvaronavičiené, 2018). 


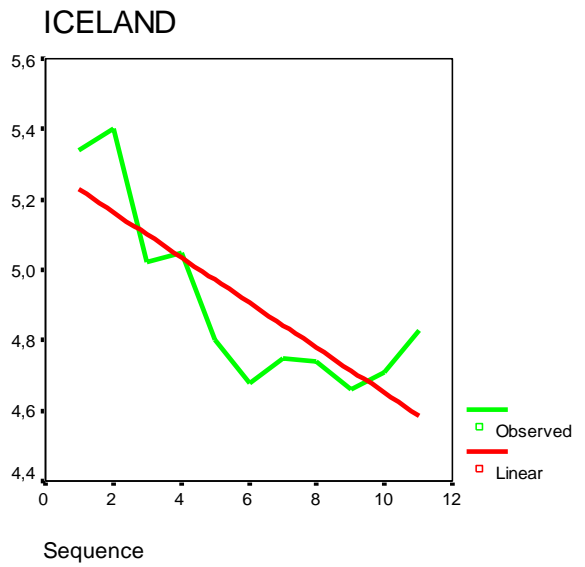

Fig.1. Growth line of Iceland created by the regressive curve estimation method, the Global Competitiveness Index, 2005-2015

Source: elaborated by the authors using SPSS software on the basis of Lopez-Claros et al., 2005; Lopez-Claros, 2006; Lopez-Claros, Schwab, 2007; Schwab, 2008, 2009, 2010, 2011, 2012, 2013, 2014, 2015

The research problem, which is being solved by the authors within the framework of this article, can be defined in the following way: we do not know whether the social and economic interactions which Iceland has promote its sustainable territory development (in the center of which is well-being of the people residing in the territory) or they restrain this development, i.e. what the role of Iceland's social and economic interactions in its sustainable territory development is. It is necessary to know it, so in case of identifying the significance of these interactions to effectively manage them, developing the ones which promote Iceland's sustainable territory development, and limiting the ones which restrain this.

Following the Human Development Report 2013 which argues that "the South needs the North, and increasingly the North needs the South" (UNDP, 2013) it could be suggested that one of the best sources of sustainable development for every territory is interconnection with other parts of the world (Azamatova et al., 2017). Within this research above-mentioned "other parts of the world" methodologically have been defined as "worldseconomies". F. Braudel defines three characteristics of a "world-economy": (1) a "world-economy" covers definite geographic space with natural, economic, cultural or mental borders; (2) a "world-economy" has a center - particular country; this center is not stable in a long-term period; (3) a "world-economy" has horizontal (spatial) and vertical (social) hierarchy (Braudel, 1967).

As a research hypothesis the authors suggest that Iceland's social and economic interactions possess a certain peculiarity - looking at the interconnection of this state with other "worlds-economies" - which can, at least, partially explain a dramatic decrease in the level of competitiveness in the highly-developed Iceland which was observed in the 2000s. Based on the above-mentioned methodological approach of the spatial economics it is possible to anticipate that challenges of Iceland's sustainable territory development are greatly determined by the fact that Iceland's social and economic interactions are not diversified enough between "worlds-economies" currently existed in the global economic space.

The remainder of the paper is organized as follows: Section 2 provides literature review on sustainable territory development of Iceland within the context of modern "worlds-economies", Section 3 outlines research methodology followed by a description of the empirical data and analysis in Section 4, Section 5 presents the results and discussion, and, finally, Section 6 offers conclusions. 


\section{Literature review on sustainable territory development of Iceland within the context of modern "worlds- economies"}

In modern scientific literature, the most frequent is the indication on two "worlds-economies" dominant in the global space: the first one with the center in the United Kingdom-the USA', the second one - with the center in China (Zoega, 2013; Kiva, 2014; Efremenko and Meleshkina, 2014; Delyagin, 2015; Cihelkova et al., 2017), i.e. provisionally the North and the South if we use the concepts provided by the Human Development Report 2013.Possibly, Iceland's social and economic interactions will also, especially in recent years, gravitate toward either the North or the South. However, as in scientific literature there are also other definitions of smaller "worlds-economies", for example, Atlantic economy (Barry, 2014), Tiger economy (Kirkby, 2012) etc., the authors suggest their own empirical interpretation of modern "worlds-economies" (Boronenko et al., 2015; Boronenko and Lavrinenko, 2016).

In their previous publications the authors have chosen two key indicators as a methodological basis for identification and empirical interpretation of modern "worlds-economies": the use of natural resources (within the framework of this research - use of energy), and the quality of social infrastructure. Why exactly these indicators? First of all, the challenging and recognized by the world scientific community limitation of natural resources which are not enough to provide comfort for all world population (to provide them not for everybody is inhuman and this is a permanent reason for conflicts and remodeling of the world) is a natural bound for the further increase in production and consumption, i.e. economic growth according to consumption-driven capitalist economy (Meadows et al., 1972, 2004; Lahart et al., 2008; Global Footprint Network and Mediterranean Ecological Footprint Initiative, 2016). Moreover, "the resource constraints foreseen by the Club of Rome are more evident today than at any time since the 1972 publication of the think tank's famous book, "The Limits of Growth" (Lahart et al., 2008). The classical option (in according to this limitation) offered by the Club of Rome is to encourage social and economic patterns that would satisfy the needs of people under the minimal use of natural resources (Meadows et al., 1972). Later some researchers argued that "recent economic research shows that the physical limits to natural resource supply do not cause any serious effects on economic growth. This is because growth depends more strongly on technical development, education, and economic policy" (Tahvonen, 1998). In their previous publications the authors of the article and other researchers proved consistently that this is true only for the countries which are - according to the classification worked out by the World Economic Forum (LopezClaros et al., 2005) - at the innovation-driven stage (Boronenko, 2007, 2009, 2014; Stankevics et al., 2014). But for countries which are at the efficiency-driven stage and especially at the factor-driven stage, exactly basic factor conditions such as low-cost labour and unprocessed natural resources are the dominant basis of competitive advantage and exports (Schwab, 2012).

Therefore, the Club of Rome in their classical work "The Limits of Growth" stated that "it is possible to alter this growth trends andto establish a condition of ecological and economic stability that is sustainable far into the future. The state of global equilibrium could be designed so that the basic material needs of each person on the Earth are satisfied and each person has an equal opportunity to realize his individual human potential" (Meadows et al., 1972). How is it possible to achieve sustainable territory development not consuming much energy and other natural resources but at the same time striving for the well-being of the population, i.e. for the "production of qualitative people"?

\footnotetext{
$\dagger$ Here the authors do not separate the UK from the USA perceiving the USA as a historically established "subsidiary" of England, which is still "the heart" of market-capitalist "world-economy".
} 
The International Journal

ENTREPRENEURSHIP AND SUSTAINABILITY ISSUES

ISSN 2345-0282 (online) http://jssidoi.org/jesi/

2018 Volume 5 Number 3 (March)

http://doi.org/10.9770/jesi.2018.5.3(1)

R. E. Hall and Ch. I. Jones in their article "Why Do Some Countries Produce So Much More Output per Worker than Others?" argue that the primary, fundamental determinant of a country's long-run economic performance is its social infrastructure, i.e. institutions and government policies (Hall and Jones, 1998). Social infrastructure gives incentives for productive activities or predatory behaviour, and workers choose between production and diversion depending on existing quality of social infrastructure in their countries. Taking into consideration that territory development depends not only on the availability of resources as such but also on the possibility to use them efficiently (Pakholok, 2013; Boronenko and Drezgic, 2014), it has to be consider that such possibility is determined by institutional environment within the country, i.e. by the country's social infrastructure which can either promote or impede a productive use of the resources available in the country. Individual achievements in health, education and income, while essential, do not guarantee in human development if social conditions constrain individual achievements (UNDP, 2013).

The World Economic Forum also argues that the importance of a sound and fair institutional environment has become even more apparent during the recent economical and financial crisis and is especially crucial for further solidifying the fragile recovery, given the increasing role played by the state at the international level and for the economies of many countries. The quality of institutions has a strong bearing on competitiveness and growth. It influences investment decisions and the organization of production and plays a key role in the ways in which societies distribute the benefits and bear the costs of development strategies and policies (Schwab, 2014).

So, further empirical identification of current "worlds-economies" was realized taking into consideration these two dimensions - energy use ("nature-friendly" dimension) and social infrastructure ("human-friendly" dimension). The set of investigated countries has to be divided into groups in relation to the average values of energy consumption and social infrastructure (Boronenko et al., 2015; Boronenko and Lavrinenko, 2016):

1) energy use per capita is higher than average meaning $-2700.00 \mathrm{~kg}$ of oil equivalent - within the set of investigated countries, but the index of social infrastructure is lower than average meaning -4.05 points within the set of investigated countries, i.e. the bad situation in terms of both indicators;

2) energy use per capita is lower than average meaning - $2700.00 \mathrm{~kg}$ of oil equivalent - within the set of investigated countries, and the index of social infrastructure is lower than average meaning -4.05 points - within the set of investigated countries, i.e. the good situation in terms of energy use, but the bad one in terms of social infrastructure;

3) energy use per capita is higher than average meaning $-2700.00 \mathrm{~kg}$ of oil equivalent - within the set of investigated countries, and the index of social infrastructure is higher than average meaning -4.05 points - within the set of investigated countries, i.e. the bad situation in terms of energy use, but the good one in terms of social infrastructure;

4) energy use per capita is lower than average meaning - $2700.00 \mathrm{~kg}$ of oil equivalent - within the set of investigated countries, but the index of social infrastructure is higher than average meaning -4.05 points - within the set of investigated countries, i.e. the good situation in terms of both indicators.

The largest group - practically a half - in the set of investigated countries (most likely also in the world) is comprised of the countries - "ecologists with poor social infrastructure". The main feature of this "worldeconomy" is a relatively low energy use per capita, although the development level of social infrastructure does not allow the countries of this "world-economy" to achieve the main aim of territory development - human well- 
being (Sen, 1983; Todaro and Smith, 2011; ulHaq, 1995; Thirlwall, 2011; Lonska and Boronenko, 2012; Lonska, 2014), as the available country's resources cannot be used at their utmost for the territory development in general, but just for the development of certain privileged layers of society due to high level of crime, corruption, favouritism, etc.

The second largest group (32 countries) is comprised of the countries opposite to the first group in terms of both indicators - "energy consumers with strong social infrastructure". They are mainly the economically developed countries of Western Europe, Scandinavia and North America (including Iceland), as well as oil Muslim countries which consume quite a lot of energy, but - surprisingly for the authors - they have a strong social infrastructure favorable for a person which enables the efficient distribution and use of available resources.

The analysis of the data shows that on the background of the above mentioned relatively large "worldseconomies" - "ecologists with poor social infrastructure" and "energy consumers with strong social infrastructure" - there appear the beginnings of new "worlds-economies" which most probably are new centers of the future dominant "worlds-economies". These two groups of countries - "energy consumers with poor social infrastructure" and "ecologists with strong social infrastructure" - from the viewpoint of territory development are the examples of complete opposites: the first group of countries is characterized by poor situation in terms of energy use as well as social infrastructure (they are, first of all, the countries with "resources' economies", which have not established a strong social infrastructure, e.g. Russia); the second group of countries is vice versa characterized by a good situation in the sphere of energy use as well as social infrastructure (they are the groups of countries overspread around the world such as the groups of countries in South Asia, including China as the most significant part of this "world-economy", in South-East Africa, Latin America and Mediterranean area).

In their previous publications the authors single out provisional leaders - politically and economically important and large countries of the identified "worlds-economies" (which enables to more easily perceive and identify the nature of each "world-economy" in the run of scientific debates) (Boronenko and Lavrinenko, 2016):

1) the leader of the "energy consumers with poor social infrastructure" - Russia;

2) the leaders of the"ecologists with poor social infrastructure" - Brazil and India;

3) the leaders of the"energy consumers with strong social infrastructure" - USA and UK;

4) the leader of the "ecologists with strong social infrastructure" - China.

At the moment, the world is undergoing an active transformation, when it is extremely important to understand into which "worlds-economies" the world is divided today and what the essence and role of each of them are. In the Introduction of the article the opinion of the Human Development Report 2013 on the presence of two "worlds-economies" in the modern global world - the growing South and the crisis North has been discussed (UNDP, 2013). The Russian economist M. Delyagin, Director of the Problems Issued by Globalization Institute, in his report at the scientific-practical conference "China and Russia in a Changing World" (Beijing, May 4, 2015) states that "in the economy a shaping division of a global financial market into the dollar, euro and yuan zones is already evident. In politics it is a restoration of a bipolar confrontation between USA and China" (Delyagin, 2015). In general, M. Delyagin is inclined to divide the global world into the western-northern and eastern-southern "worlds-economies". Taking into consideration the arguments of the abovementioned approaches towards a provisional division of the global economic environment into "worlds-economies", the authors suggest their own the above described approach trying to find more or less stable "worlds-economies" on 


\section{The International Journal}

ENTREPRENEURSHIP AND SUSTAINABILITY ISSUES

ISSN 2345-0282 (online) http://jssidoi.org/jesi/

2018 Volume 5 Number 3 (March)

http://doi.org/10.9770/jesi.2018.5.3(1)

the basis of two essential characteristics - energy use and social infrastructure, i.e. to what extent modern countries are nature-friendly and human-friendly (Boronenko et al., 2015; Boronenko and Lavrinenko, 2016).

Iceland belongs to the group of "energy consumers with strong social infrastructure" ("the USA's/the UK's group") within the system of modern "worlds-economies" identified by the authors. Moreover, the average level of use of energy resources per capita for the period under review in Iceland is one of the highest - second place after Qatar (World Bank, 2016) among 124 countries. Probably, it can be partially explained by northern climate, and partially by the excessive involvement of Iceland into huge industrial megaprojects (Johannesson, 2010a, 2010b; Johannesson et al., 2010).

When it comes to institutional environment, notwithstanding the above mentioned opinions and arguments by Icelandic researchers on corruption as a significant reason of Icelandic economic collapse (Benediktsson and Karlsdottir, 2011; Logason, 2012), Iceland has a relatively strong social infrastructure, although the average indicator of the quality of social infrastructure in the country is considerably lower than in its Scandinavian neighbors - Norway, Sweden and Finland, and it is also lower than in Singapore, New Zealand, Western Europe and Arabian oil monarchies, but it is higher than in the USA (Schwab, 2009, 2010, 2011, 2012, 2013).

Some researchers also argue that Iceland has "one of the least corrupt public administrations in the world, according to Transparency International" (Wade and Sigurgeirsdottir, 2012). At the same time, the Icelandic sociologist T. Logason in his book "Power Elites \& Corruption" (2012) examined the influence of grand corruption as a possible cause leading to the Icelandic economic collapse in 2008. He argued that "the grand corruption that can find its way into the very core of society when the elites in politics, business and academia all join forces with the aim to deceive the general public is the most dangerous form of "grand corruption" western societies can be faced with and can lead to swift economic ruin" (Logason, 2012). The researchers of the University of Iceland K. Benediktsson and A. Karlsdottir give the same reasons explaining the Icelandic economic collapse: "many have come to the following conclusion: a neoliberal political ideology that gained ascendancy in the early 1990s had nurtured a lethal mix of greed, hubris and political corruption that had been gnawing at the roots of society. The beginning of the 21st century saw the emergence of the super-rich in Iceland - a small elite that seemed to have appeared almost out of nowhere and that flaunted its wealth rather crassly at times" (Benediktsson and Karlsdottir, 2011).

It is possible to say that there is really no deep antagonism in these opposing opinions on corruption in Iceland; the crisis itself just made researchers and experts pay more attention to institutional environment in Iceland having forced them to find the flaws in it which were not paid due attention during the economic growth. The authors find the confirmation of this viewpoint in the works by Icelandic researchers:"when social structures are stable and social systems yield expected and desirable results, there is relatively less demand for institutional economics than during times of change" (Eggertsson, 2006).

Therefore, the authors think that the main reason of a dramatic decrease in Iceland's level of sustainable territory development during the last 10 years is the deterioration of its social infrastructure. The authors base their assumptions on the arguments provided by Icelandic researchers and their own results of analysis of statistics and data of the World Economic Forum's surveys. What concerns the possible ways for the improvement of the quality of social infrastructure and increase in Iceland's competitiveness, then coming back to the arguments of the Human Development Report 2013, which have been presented in the Introduction to the article. It could be suggested that one of the best source of further development for every country is efficiency interactions with other "worlds-economies". 


\section{Research methodology and methods of analysis}

In the methodological part of the article, first it is necessary to clarify the terms. The main concept of the research which has to be precisely interpreted is social and economic interactions of a country. In modern scientific literature on economics there is an interpretation of social and economic interactions of a country as its trade and migration flows, i.e. export and import, flows of emigrants and immigrants (Barry, 2014; Lavrinenko et al., 2017; Mensikovs et al., 2017). Within this article also Iceland's logistical interconnections (direct flights) will be investigated as the additional indicator of closest business and cultural interconnections of the country. Capital flows, i.e. flows of investments, will not be investigated within this article due to lack of official statistics on this issue.

The research methodology, presented in this section of the article, is based on classical spatial economics, which suggests that the state of territory development of a country depends not only on its own capacity but also on development of territories which are interconnected with investigated country (Kuenne, 1963; Takayama and Judge, 1964; Anselin, 1988, 2003; LeSage, 1999; Fotheringham et al., 2000; LeSage and Pace, 2009; Elhorst, 2014). Spatial dependence in a collection of sample data means that observations at location $i$ depend on other observations at locations $j \neq i$. Formally, we might state (LeSage, 1999):

$$
y_{i}=f\left(y_{j}\right), i=1, \ldots, n \quad j \neq i
$$

In particular, it is intended to find out:

1) with what "worlds-economies" Iceland has more intensive and significant social and economic interactions, i.e. international trade (export and import), international migration (emigration and immigration)as well aslogistical interconnections (direct flights from Reykjavik International Airport);

2) how these identified social and economic interactions influence territory development of Iceland;

3) if recommendation of Human Development Report 2013 to interact more actively with other "worldseconomies" has practical efficiency in the case of Iceland.

Further analysis is devoted to the empirical identification of social and economic interactions of Iceland - in this case, its trade and migration flows within the context of "worlds-economies" identified by the authors (in percentages from the whole figures, i.e. unit weight for every "world-economy" during last 25-27 years).

According to the researchers who study the history of Iceland, trade has always been crucial for this society (Boyer, 2009). Besides that, Icelanders have always lived in a close contact with the people who were their clients and suppliers, and, therefore, they have always been affected by them and copied them (Boyer, 2009). Therefore, the analysis of international trade flows - export and import - within the context of "worlds-economies" identified by the authors would be the most relevant way for studying social and economic interactions of Iceland in a relatively long time perspective, for which we have statistical data available.

Figure 2 and Table 1 show the data on the import of goods to Iceland for the last 27 years, also within the context of "worlds-economies" identified by the authors. 


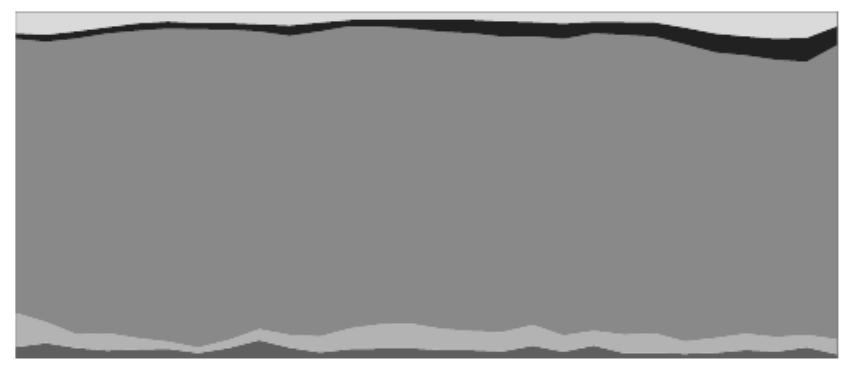

$\square$ Energy consumers with poor social infrastructure

- Ecologists with poor social infrastructure

Energy consumers with strong social infrastructure

Ecologists with strong social infrastructure

Figure 2. Export of goods from Iceland, in \% to each "world-economy", 1988-2015 Source: the authors' calculations by the Statistics Iceland, 2016a

Table 1. Export of goods from Iceland, in \% to each "world-economy", 1988-2015

\begin{tabular}{|c|c|c|c|c|c|c|}
\hline \multirow{2}{*}{ Year } & \multicolumn{4}{|c|}{ "Worlds-economies" } & \multirow{2}{*}{ Othercountries** } & \multirow{2}{*}{ Total } \\
\hline & $1 *$ & 2 & 3 & 4 & & \\
\hline 1988 & 6.16 & 1.63 & 78.91 & 9.95 & 3.35 & 100 \\
\hline 1989 & 6.50 & 2.07 & 80.89 & 6.06 & 4.48 & 100 \\
\hline 1990 & 5.51 & 2.11 & 85.41 & 3.90 & 3.07 & 100 \\
\hline 1991 & 4.34 & 1.85 & 86.49 & 4.97 & 2.35 & 100 \\
\hline 1992 & 3.22 & 2.18 & 88.71 & 3.29 & 2.60 & 100 \\
\hline 1993 & 2.67 & 2.10 & 90.35 & 2.04 & 2.84 & 100 \\
\hline 1994 & 3.14 & 1.84 & 91.86 & 1.54 & 1.62 & 100 \\
\hline 1995 & 3.12 & 1.93 & 89.61 & 2.26 & 3.08 & 100 \\
\hline 1996 & 3.47 & 2.15 & 85.93 & 3.14 & 5.31 & 100 \\
\hline 1997 & 3.83 & 3.04 & 86.33 & 3.64 & 3.16 & 100 \\
\hline 1998 & 3.00 & 2.57 & 88.04 & 4.63 & 1.76 & 100 \\
\hline 1999 & 2.22 & 1.81 & 87.25 & 6.00 & 2.72 & 100 \\
\hline 2000 & 2.21 & 1.95 & 85.94 & 7.02 & 2.88 & 100 \\
\hline 2001 & 2.01 & 2.81 & 85.13 & 7.07 & 2.98 & 100 \\
\hline 2002 & 2.16 & 3.50 & 85.79 & 6.09 & 2.46 & 100 \\
\hline 2003 & 2.20 & 3.92 & 85.98 & 5.51 & 2.39 & 100 \\
\hline 2004 & 2.59 & 4.48 & 85.33 & 5.52 & 2.08 & 100 \\
\hline 2005 & 2,83 & 4.14 & 83.34 & 5.97 & 3.72 & 100 \\
\hline 2006 & 3.28 & 4.48 & 85.59 & 4.68 & 1.97 & 100 \\
\hline 2007 & 2.78 & 3.34 & 85.87 & 4.24 & 3.77 & 100 \\
\hline 2008 & 2.84 & 3.75 & 86.52 & 5.32 & 1.57 & 100 \\
\hline 2009 & 2.97 & 4.11 & 85.65 & 5.65 & 1.62 & 100 \\
\hline 2010 & 4.45 & 4.85 & 85.80 & 3.51 & 1.39 & 100 \\
\hline 2011 & 6.18 & 5.47 & 82.42 & 4.24 & 1.69 & 100 \\
\hline 2012 & 6.97 & 5.54 & 80.33 & 4.71 & 2.45 & 100 \\
\hline 2013 & 7.66 & 6.15 & 79.98 & 4.21 & 2.00 & 100 \\
\hline 2014 & 7.39 & 6.96 & 78.86 & 3.52 & 3.27 & 100 \\
\hline 2015 & 4.01 & 5.51 & 84.98 & 4.26 & 1.24 & 100 \\
\hline
\end{tabular}

* 1 - Energy consumers with poor social infrastructure (Russia's group)

2 - Ecologists with poor social infrastructure (Brazil's/India's group)

3 - Energy consumers with strong social infrastructure (USA's/UK's group)

4 - Ecologists with strong social infrastructure (China's group)

** Countries, which had no data about energy use or/and social infrastructure 
As the data on Figure 2 and Table 1 show, the "world-economy" to which Iceland belongs itself - "energy consumers with strong social infrastructure", i.e. a market-capitalist "world-economy" - has the absolute advantage as a receiver of Icelandic export goods. Since 1988 the share of the market-capitalist "world-economy" has never gone down lower than 80 \% within the export structure of Iceland, but in 1993-1994 it even exceeded $90 \%$. In 2013-2014 there was a slight "shift" towards such "worlds-economies" as "energy consumers with poor social infrastructure" and "ecologists with poor social infrastructure", but it was an insignificant and short episode which hardly virtually changed the absolute export orientation of Iceland towards its own "world-economy".

Within the framework of this research the authors did not analyze in detail the export structure and main partners (countries), as in order to achieve the aim of this research the authors were interested only in the "worldseconomies" context. It should be shortly pointed out that the peculiarity of directions and export structure in Iceland is its "peg" - in recent years - to one country and one product, namely, the Netherlands (Statistics Iceland, 2016a) and aluminum (Statistics Iceland, 2011), which has become one of the leaders of Icelandic export along with the implementation of industrial "large scale projects" or "megaprojects" (Johannesson, 2010a, 2010b; Johannesson et al., 2010) on the east of the country in 2004.

Figure 3 and Table 2 show the data on the import of goods to Iceland for the last 27 years, also within the context of "worlds-economies" identified by the authors.

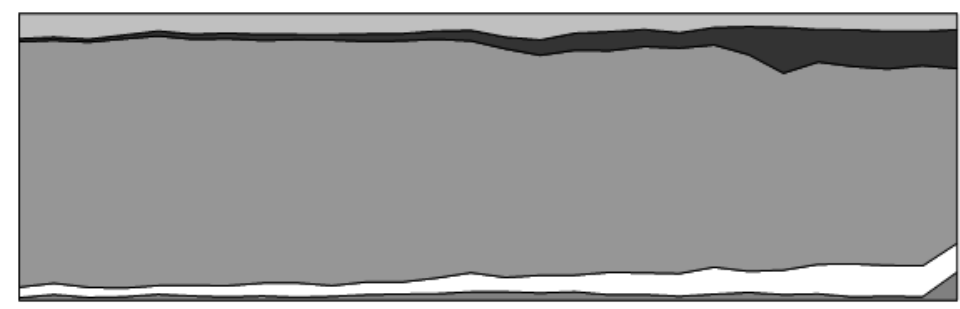

$\square$ Energy consumers with poor social infrastructure

Ecologists with poor social infrastructure

$\square$ Energy consumers with strong social infrastructure

$\square$ Ecologists with strong social infrastructure

口Others

Figure 3. Import of goods to Iceland, in \% from each "world-economy",1988-2015

Source: the authors' calculations by the Statistics Iceland, 2016b

Table 2. Import of goods to Iceland, in \% from each "world-economy”,1988-2015

\begin{tabular}{|c|c|c|c|c|c|c|}
\hline \multirow{2}{*}{ Year } & \multicolumn{4}{|c|}{ "Worlds-economies" } & \multirow{2}{*}{$\begin{array}{c}\text { Other } \\
\text { countries } * *\end{array}$} & \multirow{2}{*}{ Total } \\
\hline & $1 *$ & 2 & 3 & 4 & & \\
\hline 1988 & 8.80 & 1.02 & 85.57 & 3.63 & 0.98 & 100 \\
\hline 1989 & 8.24 & 1.12 & 84.69 & 3.93 & 2.02 & 100 \\
\hline 1990 & 8.96 & 1.05 & 85.47 & 3.50 & 1.02 & 100 \\
\hline 1991 & 7.56 & 1.32 & 86.83 & 3.03 & 1.26 & 100 \\
\hline 1992 & 6.15 & 1.69 & 86.99 & 3.05 & 2.12 & 100 \\
\hline 1993 & 7.21 & 1.82 & 85.77 & 3.66 & 1.54 & 100 \\
\hline 1994 & 6.86 & 1.92 & 86.09 & 3.91 & 1.22 & 100 \\
\hline 1995 & 7.25 & 2.18 & 84.53 & 4.50 & 1.54 & 100 \\
\hline 1996 & 7.27 & 1.84 & 84.80 & 4.97 & 1.12 & 100 \\
\hline
\end{tabular}


The International Journal

ENTREPRENEURSHIP AND SUSTAINABILITY ISSUES

ISSN 2345-0282 (online) http://jssidoi.org/jesi/

2018 Volume 5 Number 3 (March)

http://doi.org/10.9770/jesi.2018.5.3(1)

\begin{tabular}{|l|l|l|l|l|l|l|}
\hline $\mathbf{1 9 9 7}$ & 7.29 & 1.97 & 85.64 & 3.71 & 1.39 & 100 \\
\hline $\mathbf{1 9 9 8}$ & 7.12 & 2.61 & 83.88 & 4.42 & 1.97 & 100 \\
\hline $\mathbf{1 9 9 9}$ & 7.06 & 2.49 & 84.08 & 4.17 & 2.20 & 100 \\
\hline $\mathbf{2 0 0 0}$ & 6.14 & 2.86 & 83.22 & 5.44 & 2.34 & 100 \\
\hline $\mathbf{2 0 0 1}$ & 5.88 & 3.68 & 80.81 & 6.68 & 2.95 & 100 \\
\hline $\mathbf{2 0 0 2}$ & 8.23 & 4.15 & 79.61 & 5.01 & 3.00 & 100 \\
\hline $\mathbf{2 0 0 3}$ & 9.23 & 5.36 & 76.67 & 6.14 & 2.60 & 100 \\
\hline $\mathbf{2 0 0 4}$ & 6.87 & 5.97 & 78.36 & 5.79 & 3.01 & 100 \\
\hline $\mathbf{2 0 0 5}$ & 6.35 & 6.65 & 77.23 & 7.82 & 1.95 & 100 \\
\hline $\mathbf{2 0 0 6}$ & 5.60 & 5.98 & 78.82 & 7.54 & 2.06 & 100 \\
\hline $\mathbf{2 0 0 7}$ & 6.74 & 5.37 & 78.53 & 7.92 & 1.44 & 100 \\
\hline $\mathbf{2 0 0 8}$ & 4.90 & 6.07 & 77.47 & 9.40 & 2.16 & 100 \\
\hline $\mathbf{2 0 0 9}$ & 4.62 & 9.76 & 75.51 & 7.34 & 2.77 & 100 \\
\hline $\mathbf{2 0 1 0}$ & 4.85 & 15.95 & 68.66 & 8.53 & 2.01 & 100 \\
\hline $\mathbf{2 0 1 1}$ & 5.57 & 11.36 & 70.53 & 10.26 & 2.28 & 100 \\
\hline $\mathbf{2 0 1 2}$ & 5.71 & 12.78 & 68.80 & 11.48 & 1.23 & 100 \\
\hline $\mathbf{2 0 1 3}$ & 6.22 & 13.11 & 68.50 & 10.69 & 1.48 & 100 \\
\hline $\mathbf{2 0 1 4}$ & 6.19 & 11.95 & 69.84 & 10.78 & 1,24 & 100 \\
\hline $\mathbf{2 0 1 5}$ & 5.65 & 13.58 & 60.85 & 10.01 & 9.91 & 100 \\
\hline
\end{tabular}

* 1 - Energy consumers with poor social infrastructure (Russia's group)

2 - Ecologists with poor social infrastructure (Brazil's/India's group)

3 - Energy consumers with strong social infrastructure (USA's/UK's group)

4 - Ecologists with strong social infrastructure (China's group)

** Countries, which had no data about energy use or/and social infrastructure

Source: the authors' calculations by the Statistics Iceland, 2016b

According to the data summarized and presented by the authors on Figure 3 and Table 2, the import of goods to Iceland is more diversified in relation to "worlds-economies" supplying these goods as compared to the export. The market-capitalist "world-economy" - "energy consumers with strong social infrastructure" ("the USA's/the UK's group") - is an absolute leader, although with an increasingly declining share within the general structure of import of goods to Iceland. If in 1988 the share of goods by the market-capitalist "world-economy" comprised more than $85 \%$ within the structure of Icelandic goods imports, since the beginning of the 2000s it has never exceeded $80 \%$, sharply decreased after the crisis and reached $60 \%$ in 2015.

In its turn, after the 2008 crisis, the share of goods imports from "ecologists with poor social infrastructure" ("Brazil's /India's group") has increased significantly. It should be reminded that for a short period of time - in 2013-2014 - the share of export to Iceland of goods from this "world-economy" increased, but still the increased share of import from "ecologists with poor social infrastructure" to Iceland remains the established trend. Not analyzing the reasons for a such trend (as it goes beyond the scope of this research), it should be noted that the expansion of interactions with other "worlds-economies" in the post-crisis period happens mainly in the process of importing goods, not exporting (possibly, because of the difference in the price level on goods produced in "energy consumers with strong social infrastructure" and in "ecologists with poor social infrastructure"). But the most important thing is that the expansion of economic and social interactions through trade flows happens anyway.

It should also be pointed out that in Iceland's import-export practice, as well as in its industry there are "large scale projects" (related mainly to offshore zones) which really sharply but for a short period of time change the structure of export and import of goods. For example, $2.02 \%$ of total export in 1996 was from the Cayman Islands (with the population of a little more than 56 thousand), $2.17 \%$ of total export in 2007 - from the Virgin 
The International Journal

ENTREPRENEURSHIP AND SUSTAINABILITY ISSUES

ISSN 2345-0282 (online) http://jssidoi.org/jesi/

2018 Volume 5 Number 3 (March)

http://doi.org/10.9770/jesi.2018.5.3(1)

Islands (Statistics Iceland, 2016a), in 2015 the goods from Bermuda (with the population of a little more than 64 thousand) comprised $6.58 \%$ of total import (Statistics Iceland, 2016b).

From the viewpoint of the main emphasis of this research on "worlds-economies", the peculiarity of the process of emigration from Iceland is its absolute orientation on the same "world-economy" which Iceland itself belongs to, i.e. on "energy consumers with strong social infrastructure" (the USA's/the UK's group). Denmark, Norway, Sweden, the UK and the USA receive the main flow of Icelanders-immigrants. In 2012 these 5 countries received $83.1 \%$ of the general number of Icelandic emigrants, in $2013-81.7 \%$, in $2014-80.8 \%$.

If the UK and the USA during the period under research attracted a persistently small number of emigrants from Iceland, three Scandinavian states - Denmark, Norway and Sweden - have the periods which were especially attractive for Icelandic emigrants. For example, in Sweden the period 1989-1990 was the most attractive when more than $45 \%$ of all Icelandic emigrants chose this country. Later, in 2004-2007, Denmark became the most popular, when almost half of Icelandic emigrants left for it (it has to be reminded that this was the period of boom in Iceland, when the emigration flow was lower than usual). Icelanders started to choose Norway as the target country for their emigration $-30 \%$ and more from the total number of emigrants after 2009. It still remains the main direction for emigration flow from Iceland.

Taking into consideration the peculiarities of direction and intensity of Icelandic emigration, it can be rather referred to as cultural-economic not just economic as it happens in Eastern European countries, for example in Latvia, Lithuania, Poland, etc.

During the analysis of the migration flows to and from Iceland the authors compared the absolute meanings of international emigration and immigration in order to qualitatively compare these two flows in the period since 1986. As results of this analysis demonstrate, the dominance of one or another process - emigration or immigration has repeatedly changed during the last 30 years. Four such periods can be conceptually singled out:

1) 1986-2004 - the intensity of the emigration process of Icelanders from the country quantitatively exceeded the immigration indexes, and during some periods within this time interval - dramatically (for example, in 1995 the flow of emigration 4 times exceeded the immigration flow);

2) 2005-2008 - the period of boom in the Icelandic financial economy, when the immigration to the country significantly exceeded the emigration (in 2007 almost 3 times);

3) 2009-2012 - the period of financial and economic recession, when the emigration flow again quantitatively exceeded the immigration flow to Iceland;

4) 2013-2014 - the period of slow revival of economy after the crisis; the dominant of migration flows changed again in favor of immigration to the country, i.e. there were considerably more immigrants than Icelanders who were leaving the country, and, the chances are that this tendency exists now.

In addition to two previously analysed types of Iceland's interactions with other "worlds-economies", the authors propose to take into consideration such type of logistical interactions as direct flights. The authors pay special attention to this type of interactions, as the availability of direct flights encourages a tighter and more frequent economic, social and cultural interaction between the related countries.

Prior to carrying out the quantitative analysis of influence of existing social and economic interactions on sustainable territory development of Iceland, the authors identified the main partners to which Iceland is most tightly connected by either trade, or migration, or logistical external interactions.

\footnotetext{
$\$$ All these islands are overseas territories of a market-capitalist "world-economy", and the authors admit that to relate these islands to the group "other countries" might be considered not fully correct.
} 
In order to quantitatively assess the influence of existing social and economic interactions on sustainable territory development of Iceland, the authors carried out the linear regression analysis on the basis of the panel data about the scores of the Global Competitiveness Index (GCI) by the scale from 1 till 7 as well as changes of GCI in all main countries covered by investigated social and economic interactions of Iceland during the period of 20052015.

The authors make an equation of growth lines for every country from the list of main partners of Iceland in international trade, migration and air logistics (including the Iceland itself) using the following formula (Dubrova, 2003):

$$
y=b_{0}+b_{1} * t
$$

where $y$ - the Global Competitiveness Index, score; $t$ - time in years; $b_{0}$ - average weighted linear GCI for the period of 2005-2015; $b_{1}$ - average weighted linear annual change of GCI for the period of 2006-2015.

Since the final task required to achieve the aim of the research was the following one: to analyse influence of existing social and economic interactions on territory development of Iceland, the authors attempted to analyse this influence by means of a linear regression analysis where the dependant variable is annual absolute change of the GCI's score of Iceland for the period of 2006-2015, but independent variables - annual absolute changes of the GCI's score of Iceland's main partners on social and economic interactions (international trade, migration and logistics) for the period of 2006-2015.

\section{Empirical data and analysis}

As Table 3 shows some countries - in particular such as the USA, Spain, the UK and Germany - are among Iceland's main partners in several types of social and economic interactions at the same time. And virtually all of them, except China, Brazil and Lithuania, belong to the same "world-economy" (the same one which Iceland itself belongs to): "energy consumers with strong social infrastructure" ("the USA's/the UK's group").

Table 3. Iceland's main partners in export and import of goods, international emigration and immigration, and logistical partners (direct flights)

\begin{tabular}{|c|c|c|c|}
\hline \multicolumn{2}{|c|}{ Main partners in export of goods, 2015} & \multicolumn{2}{|c|}{ Main partners in import of goods, 2015} \\
\hline Countries & $\begin{array}{l}\text { Unit weight from total } \\
\text { export of Iceland, \% }\end{array}$ & Countries & $\begin{array}{l}\text { Unit weight from total } \\
\text { import of Iceland, \% }\end{array}$ \\
\hline The Netherlands & 27.96 & Norway & 10.08 \\
\hline Spain & 12.63 & Germany & 7.67 \\
\hline UK & 11.40 & China & 7.18 \\
\hline Germany & 8.26 & Brazil & 6.59 \\
\hline USA & 5.37 & USA & 6.54 \\
\hline \multicolumn{2}{|c|}{ Main partners in emigration, 2014} & \multicolumn{2}{|c|}{ Main partners in immigration, 2014} \\
\hline Countries & $\begin{array}{l}\text { Unit weight from total } \\
\text { number of emigrants } \\
\text { with Icelandic } \\
\text { citizenship, \% }\end{array}$ & Countries & $\begin{array}{c}\text { Unit weight from total } \\
\text { number of foreign } \\
\text { immigrants to Iceland, } \\
\%\end{array}$ \\
\hline Norway & 29.53 & Poland & 32.04 \\
\hline
\end{tabular}


The International Journal

ENTREPRENEURSHIP AND SUSTAINABILITY ISSUES

ISSN 2345-0282 (online) http://jssidoi.org/jesi/

2018 Volume 5 Number 3 (March)

http://doi.org/10.9770/jesi.2018.5.3(1)

\begin{tabular}{|l|c|l|c|}
\hline Denmark & 24.38 & Germany & 4.76 \\
\hline Sweden & 16.56 & Spain & 4.62 \\
\hline USA & 6.12 & USA & 4.12 \\
\hline UK & 4.24 & Lithuania & 3.91 \\
\hline \multicolumn{3}{|c|}{ Logistical partners (direct flights), 2015 } \\
\hline $\begin{array}{l}\text { Canada, the United States, the United Kingdom, the Netherlands, Denmark, Norway, Sweden, Finland, } \\
\text { Germany, France, Belgium }\end{array}$
\end{tabular}

Source: elaborated by the authors on the basis of Statistics Iceland, 2016a, 2016b, 2016c, 2016d, www.skyscanner.com

For assessment of the influence of existing social and economic interactions on sustainable territory development of Iceland, the authors carried out the linear regression analysis on the basis of the panel data about the scores of the Global Competitiveness Index (GCI) by the scale from 1 till 7 (see Table 4) as well as changes of GCI in all main countries covered by investigated social and economic interactions of Iceland during the period of 20052015 (see Table 5).

Table 4. Panel data on the Global Competitiveness Index of countries - main partners of Iceland in international trade, migration and air logistics, scores from 1 till 7, 2005-2015

\begin{tabular}{|l|c|c|c|c|c|c|c|c|c|c|c|}
\hline Countries & $\mathbf{2 0 0 5}$ & $\mathbf{2 0 0 6}$ & $\mathbf{2 0 0 7}$ & $\mathbf{2 0 0 8}$ & $\mathbf{2 0 0 9}$ & $\mathbf{2 0 1 0}$ & $\mathbf{2 0 1 1}$ & $\mathbf{2 0 1 2}$ & $\mathbf{2 0 1 3}$ & $\mathbf{2 0 1 4}$ & $\mathbf{2 0 1 5}$ \\
\hline Iceland & 5.34 & 5.40 & 5.02 & 5.05 & 4.80 & 4.68 & 4.75 & 4.74 & 4.66 & 4.71 & 4.83 \\
\hline Belgium & 5.23 & 5.27 & 5.10 & 5.14 & 5.09 & 5.07 & 5.20 & 5.21 & 5.13 & 5.18 & 5.20 \\
\hline Brazil & 4.08 & 4.03 & 3.99 & 4.13 & 4.23 & 4.28 & 4.32 & 4.40 & 4.33 & 4.34 & 4.08 \\
\hline Canada & 5.39 & 5.37 & 5.34 & 5.37 & 5.33 & 5.30 & 5.33 & 5.27 & 5.20 & 5.24 & 5.31 \\
\hline China & 4.26 & 4.24 & 4.57 & 4.70 & 4.74 & 4.84 & 4.90 & 4.83 & 4.84 & 4.89 & 4.89 \\
\hline Denmark & 5.73 & 5.70 & 5.55 & 5.58 & 5.46 & 5.32 & 5.40 & 5.29 & 5.18 & 5.29 & 5.33 \\
\hline Finland & 5.73 & 5.76 & 5.49 & 5.50 & 5.43 & 5.37 & 5.47 & 5.55 & 5.54 & 5.50 & 5.45 \\
\hline France & 5.39 & 5.31 & 5.18 & 5.22 & 5.13 & 5.13 & 5.14 & 5.11 & 5.05 & 5.08 & 5.13 \\
\hline Germany & 5.56 & 5.58 & 5.51 & 5.46 & 5.37 & 5.39 & 5.41 & 5.48 & 5.51 & 5.49 & 5.53 \\
\hline Lithuania & 4.51 & 4.53 & 4.49 & 4.45 & 4.30 & 4.38 & 4.41 & 4.41 & 4.41 & 4.51 & 4.55 \\
\hline Netherlands & 5.39 & 5.56 & 5.40 & 5.41 & 5.32 & 5.33 & 5.41 & 5.50 & 5.42 & 5.45 & 5.50 \\
\hline Norway & 5.31 & 5.42 & 5.20 & 5.22 & 5.17 & 5.14 & 5.18 & 5.27 & 5.33 & 5.35 & 5.41 \\
\hline Poland & 4.38 & 4.30 & 4.28 & 4.28 & 4.33 & 4.51 & 4.46 & 4.46 & 4.46 & 4.48 & 4.49 \\
\hline Spain & 4.80 & 4.77 & 4.66 & 4.72 & 4.59 & 4.49 & 4.54 & 4.60 & 4.57 & 4.55 & 4.59 \\
\hline Sweden & 5.55 & 5.74 & 5.54 & 5.53 & 5.51 & 5.56 & 5.61 & 5.53 & 5.48 & 5.41 & 5.43 \\
\hline UK & 5.51 & 5.54 & 5.41 & 5.30 & 5.19 & 5.25 & 5.39 & 5.45 & 5.37 & 5.41 & 5.43 \\
\hline USA & 5.85 & 5.61 & 5.67 & 5.74 & 5.59 & 5.43 & 5.43 & 5.47 & 5.48 & 5.54 & 5.61 \\
\hline
\end{tabular}

Source: Lopez-Claros et al., 2005; Lopez-Claros, 2006; Lopez-Claros, Schwab, 2007; Schwab, 2008, 2009, 2010, 2011, 2012, 2013, 2014, 2015.

Table 5. Panel data on annual absolute changes of scores of the Global Competitiveness Index of countries - main partners of Iceland in international trade, migration and air logistics, 2006-2015

\begin{tabular}{|c|c|c|c|c|c|c|c|c|c|c|}
\hline Countries & ๕̊ํํ ڤn & ఫે & $\stackrel{\text { ¿ }}{\circ}$ & 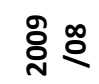 & 웅 응 & 공요 & 골 & $\stackrel{m}{\tilde{N}} \underset{\sim}{*}$ & $\stackrel{\sim}{\sim} \stackrel{m}{\sim}$ & 号 ت \\
\hline Iceland & +0.06 & -0.38 & +0.03 & -0.25 & -0.12 & +0.07 & -0.01 & -0.08 & +0.05 & +0.12 \\
\hline Belgium & -0.04 & +0.17 & -0.04 & +0.05 & +0.02 & $\begin{array}{l}-0.13 \\
\end{array}$ & -0.01 & +0.08 & -0.05 & +0.02 \\
\hline Brazil & -0.05 & \begin{tabular}{|c|}
-0.04 \\
\end{tabular} & +0.14 & +0.10 & +0.05 & +0.04 & +0.08 & $\begin{array}{l}-0.07 \\
\end{array}$ & +0.01 & $\begin{array}{l}-0.26 \\
\end{array}$ \\
\hline Canada & $\begin{array}{l}-0.02 \\
\end{array}$ & $\begin{array}{l}-0.03 \\
\end{array}$ & +0.03 & \begin{tabular}{|l|}
-0.04 \\
\end{tabular} & $\begin{array}{l}-0.03 \\
\end{array}$ & +0.03 & $\begin{array}{l}-0.06 \\
\end{array}$ & $\begin{array}{l}-0.07 \\
\end{array}$ & +0.04 & +0.07 \\
\hline China & -0.02 & +0.33 & +0.13 & +0.04 & +0.10 & +0.06 & -0.07 & +0.01 & +0.05 & 0.00 \\
\hline
\end{tabular}


The International Journal

ENTREPRENEURSHIP AND SUSTAINABILITY ISSUES

ISSN 2345-0282 (online) http://jssidoi.org/jesi/

2018 Volume 5 Number 3 (March)

http://doi.org/10.9770/jesi.2018.5.3(1)

\begin{tabular}{|l|c|c|c|c|c|c|c|c|c|c|}
\hline Denmark & -0.03 & -0.15 & +0.03 & -0.12 & -0.14 & +0.08 & -0.11 & -0.11 & +0.11 & +0.04 \\
\hline Finland & +0.03 & -0.27 & +0.01 & -0.07 & -0.06 & +0.10 & +0.08 & -0.01 & -0.04 & -0.05 \\
\hline France & -0.08 & -0.13 & +0.04 & -0.09 & 0.00 & +0.01 & -0.03 & -0.06 & +0.03 & +0.05 \\
\hline Germany & +0.02 & -0.07 & -0.05 & -0.09 & +0.02 & +0.02 & +0.07 & +0.03 & -0.02 & +0.04 \\
\hline Lithuania & +0.02 & -0.04 & -0.04 & -0.15 & +0.08 & +0.03 & 0.00 & 0.00 & +0.10 & +0.04 \\
\hline Netherlands & +0.17 & -0.16 & +0.01 & -0.09 & +0.01 & +0.08 & +0.09 & -0.08 & +0.03 & +0.05 \\
\hline Norway & +0.11 & -0.22 & +0.02 & -0.05 & -0.03 & +0.04 & +0.09 & +0.06 & +0.02 & +0.06 \\
\hline Poland & -0.08 & -0.02 & 0.00 & +0.05 & +0.18 & -0.05 & 0.00 & 0.00 & +0.02 & +0.01 \\
\hline Spain & -0.03 & -0.11 & +0.06 & -0.13 & -0.10 & +0.05 & +0.06 & -0.03 & -0.02 & +0.04 \\
\hline Sweden & +0.19 & -0.20 & -0.01 & -0.02 & +0.05 & +0.05 & -0.08 & -0.05 & -0.07 & +0.02 \\
\hline UK & +0.03 & -0.13 & -0.11 & -0.11 & +0.06 & +0.14 & +0.06 & -0.08 & +0.04 & +0.02 \\
\hline USA & -0.24 & +0.06 & +0.07 & -0.15 & -0.16 & 0.00 & +0.04 & +0.01 & +0.06 & +0.07 \\
\hline
\end{tabular}

Source: calculated by the authors on the basis of Lopez-Claros et al., 2005; Lopez-Claros, 2006; Lopez-Claros, Schwab, 2007; Schwab, 2008, 2009, 2010, 2011, 2012, 2013, 2014, 2015

For clarity, the data in Table 5 on annual absolute changes of scores of the GCI for all countries which are Iceland's main partners in international trade, migration and logistics is shown in Figure 4.

As it can be seen on Figure 4, the trends of changes of scores of the GCI of the partner countries of Iceland (including Iceland itself) are visually similar - periods of growth are cyclically replaced with periods of decline, but the common line points at stagnation in the development of competitiveness of these countries, the vast majority of which belong to a capitalist "world-economy" of energy consumers with strong social infrastructure ("the USA's/the UK's group"). Nevertheless, this visual similarity should be mathematically tested, for example, with the help of creation of models of growth lines using the method of regressive curve estimation (Dubrova, 2003).

Table 6. The models of growth linesof countries - main partners of Iceland in international trade, migration and air logistics, GCI scores, 2005-2015

\begin{tabular}{|l|c|c|c|c|c|c|c|}
\hline Country & Mth & Rsq & d.f. & F & Sigf & b0 & b1 \\
\hline Iceland & LIN & 0.661 & 9 & 17.59 & 0.002 & 5.2924 & -0.0642 \\
\hline Belgium & LIN & 0.006 & 9 & 0.06 & 0.814 & 5.1747 & -0.0015 \\
\hline Brazil & LIN & 0.371 & 9 & 5.30 & 0.047 & 4.0433 & +0.0263 \\
\hline Canada & LIN & 0.637 & 9 & 15.78 & 0.003 & 5.3976 & -0.0140 \\
\hline China & LIN & 0.748 & 9 & 26.74 & 0.001 & 4.3193 & +0.0635 \\
\hline Denmark & LIN & 0.814 & 9 & 39.37 & 0.000 & 5.7331 & -0.0490 \\
\hline Finland & LIN & 0.295 & 9 & 3.77 & 0.084 & 5.6436 & -0.0195 \\
\hline France & LIN & 0.706 & 9 & 21.61 & 0.001 & 5.3238 & -0.0256 \\
\hline Germany & LIN & 0.036 & 9 & 0.34 & 0.575 & 5.5044 & -0.0039 \\
\hline Lithuania & LIN & 0.001 & 9 & 0.01 & 0.917 & 4.4549 & 0.0008 \\
\hline Netherlands & LIN & 0.034 & 9 & 0.31 & 0.590 & 5.4024 & +0.0040 \\
\hline Norway & LIN & 0.049 & 9 & 0.46 & 0.513 & 5.2335 & +0.0065 \\
\hline Poland & LIN & 0.591 & 9 & 12.99 & 0.006 & 4.2773 & +0.0209 \\
\hline Spain & LIN & 0.569 & 9 & 11.88 & 0.007 & 4.7613 & -0.0226 \\
\hline Sweden & LIN & 0.461 & 9 & 7.70 & 0.022 & 5.6445 & -0.0182 \\
\hline UK & LIN & 0.024 & 9 & 0.22 & 0.650 & 5.4158 & -0.0049 \\
\hline USA & LIN & 0.388 & 9 & 5.71 & 0.041 & 5.7336 & -0.0250 \\
\hline
\end{tabular}

Source: calculated by the authors using SPSS software on the basis of Lopez-Claros et al., 2005; Lopez-Claros, 2006; Lopez-Claros, Schwab, 2007; Schwab, 2008, 2009, 2010, 2011, 2012, 2013, 2014, 2015.

Table 6 presents mathematically, and Appendix - graphically that the estimated growth lines of investigated countries are not really identical but sometimes are not identical at all to the trend of Iceland's competitiveness. It can be stated that Iceland's partners such as Canada, the USA, Denmark, Sweden, Finland, France and Spain 
The International Journal

ENTREPRENEURSHIP AND SUSTAINABILITY ISSUES

ISSN 2345-0282 (online) http://jssidoi.org/jesi/

2018 Volume 5 Number 3 (March)

http://doi.org/10.9770/jesi.2018.5.3(1)

develop following the falling trend similar to Iceland's one (see Table 6 and Appendix). The growth linesof Germany, the UK, Belgium and Lithuania in their turn demonstrate a minimal negative slope close to a horizontal line. Norway and the Netherlands turn their growth lines towards the rise, minimal though. Finally, Poland, Brazil and China demonstrate explicitly positive growth trends. It is interesting that the last two countries - Brazil and China - represent other "worlds-economies", while all the rest of the countries belong to the same "worldeconomy" as Iceland. It should be mentioned that Poland which is included into a capitalist "world-economy" according to its indexes of energy consumption and social infrastructure is very close to "Brazil's/India's group" - "ecologists with poor social infrastructure".

The mathematical and graphical analyses of the competitiveness trends of the countries which are Iceland's main partners in international trade, migration and logistics showed that not all of them during the last 10 years have been developing according to the falling trend similar to Iceland's one (it especially refers to the countries which belong to other "worlds-economies").

Since the final task required to achieve the aim of the research was the following one: to analyse influence of existing social and economic interactions on territory development of Iceland, the authors attempted to analyse this influence by means of a regression analysis where the dependant variable is annual absolute change of the GCI's score of Iceland for the period of 2006-2015, but independent variables - annual absolute changes of the GCI's score of Iceland's main partners on social and economic interactions (international trade, migration and logistics) for the period of 2006-2015.

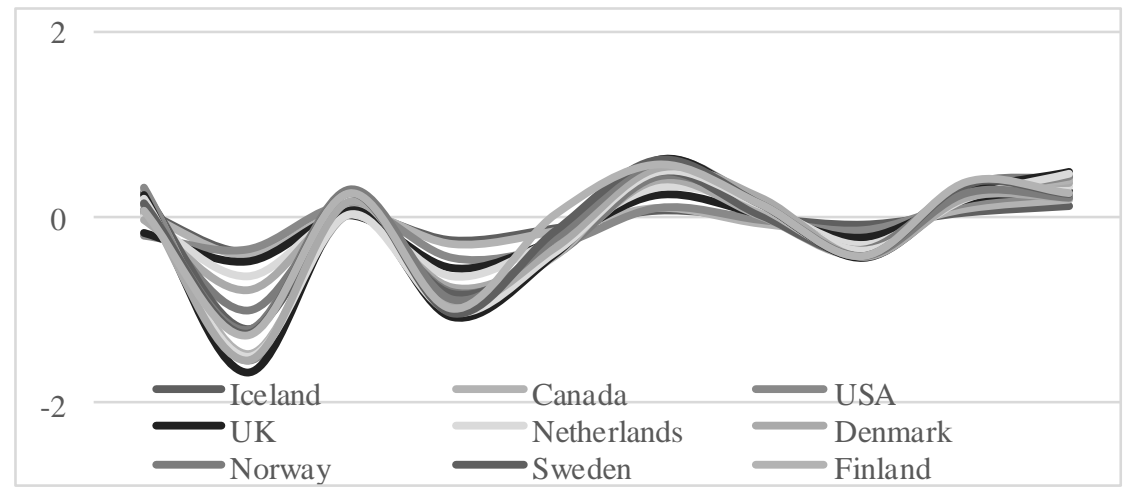

Fig.4. Annual absolute changes of scores of the Global Competitiveness Index of countries - main partners of Iceland in international trade, migration and air logistics, 2006-2015

Source: calculated by the authors on the basis of the panel data from the Table 5

\section{Results and discussion}

The regression analysis shows the following results for the most significant social and economic interactions of Iceland within export of goods and immigration of foreigners:

$$
y=-0.001+1.675 * x_{1}+0.604 * x_{2}
$$

where $y$ - annual absolute change of the GCI's score of Iceland; $x_{1}$ - annual absolute change of the GCI's score of Spain; $x_{2}$ - annual absolute change of the GCI's score of the USA. 
The International Journal

ENTREPRENEURSHIP AND SUSTAINABILITY ISSUES

ISSN 2345-0282 (online) http://jssidoi.org/jesi/

2018 Volume 5 Number 3 (March)

http://doi.org/10.9770/jesi.2018.5.3(1)

It practically means that the annual absolute increase of the GCI's score in Spain for 1 point (for example, from 5 to 6) causes an increase of Iceland's GCI for 1.675 points, i.e. from 5 to 6.68), but the annual absolute increase of the GCI's score in the USA for one point (for example, from 5 to 6) causes an increase of Iceland's GCI for 0.604 points, i.e. from 5 to 5.6). All other of Iceland's most significant partners in export and immigration - the Netherlands, the UK, Germany, Poland and Lithuania (see Table 1) - were excluded from regressive equation as non-significant variables which are not influencing an annual absolute change of the GCI's score in Iceland. The first - constant - element of regressive equation means Iceland's own trend of annual absolute change of the GCI's score without influence of Spain and the USA. So, it has to be concluded that export of goods to Spain and the USA as well as immigration from these countries positively influence negative trend of territory development of Iceland (measured by the GCI).

Further regression analysis shows the following results for the most significant social and economic interactions of Iceland within import of goods:

$$
y=0.028-1.277 * x_{1}+1.191 * x_{2}+0.442 * x_{3}
$$

where $y$ - annual absolute change of the GCI's score of Iceland; $x_{1}$ - annual absolute change of the GCI's score of China; $x_{2}$ - annual absolute change of the GCI's score of Norway; $x_{3}$ - annual absolute change of the GCI's score of the USA.

It practically means that the annual absolute increase of the GCI's score in China for one point (for example, from 5 to 6) causes a decrease of Iceland's GCI for 1.277 points, i.e. from 5 to 3.72), the annual absolute increase of the GCI's score in Norway for one point (for example, from 5 to 6) causes an increase of Iceland's GCI for 1.191 points, i.e. from 5 to 6.2) but the annual absolute increase of the GCI's score in the USA for one point (for example, from 5 to 6) causes an increase of Iceland's GCI for 0.442 points, i.e. from 5 to 5.4 ). All the other of Iceland's most significant partners in import of goods -Germany and Brazil (see Table 1) - were excluded from regressive equation as non-significant variables which are not influencing an annual absolute change of the GCI's score in Iceland. So, it has to be concluded that import of goods from Norway and the USA positively influences the trend of sustainable territory development of Iceland (measured by the GCI), but import of goods from China - vice versa - negatively influences the trend of territory development of Iceland.

Further regression analysis shows the following results for the most significant social and economic interactions of Iceland within air logistics, i.e. direct flights:

$$
y=-0.023-1.491 * x_{1}+0.922 * x_{2}
$$

where $y$ - annual absolute change of the GCI's score of Iceland; $x_{1}$ - annual absolute change of the GCI's score of Belgium; $x_{2}$ - annual absolute change of the GCI's score of France.

It practically means that the annual absolute increase of the GCI's score in Belgium for one point (for example, from 5 to 6) causes a decrease of Iceland's GCI for 1.491 points, i.e. from 5 to 3.5), but the annual absolute increase of the GCI's score in France for one point (for example, from 5 to 6) causes an increase of Iceland's GCI for 0.922 points, i.e. from 5 to 5.9). All the other of Iceland's most significant partners in air logistics - Canada, the USA, the UK, the Netherlands, Denmark, Norway, Sweden, Finland and Germany (see Table 1) - were excluded from regressive equation as non-significant variables which are not influencing an annual absolute change of the GCI's score in Iceland. So, it has to be concluded that partnership with France in air logistics positively influences the trend of sustainable territory development of Iceland (measured by the GCI), but with Belgium - negatively. 
The International Journal

ENTREPRENEURSHIP AND SUSTAINABILITY ISSUES

ISSN 2345-0282 (online) http://jssidoi.org/jesi/

2018 Volume 5 Number 3 (March)

http://doi.org/10.9770/jesi.2018.5.3(1)

The last regression analysis for the most significant social and economic interactions of Iceland within emigration excludes all main destinations of emigration of Icelandic citizens (see Table 1) from regressive equation as nonsignificant variables which are not influencing an annual absolute change of the GCI's score in Iceland. So, it has to be concluded that such kind of social and economic interactions as emigration of Icelandic citizens does not influence trend of territory development of Iceland.

\section{Conclusions}

The research hypothesis that Iceland's sustainable territorial development (in particular, negative trend during the last 10 years) is greatly determined by intensity and direction of Iceland's social and economic interactions, has been proved.

As the outcomes of the research showed:

1) Iceland is interconnected mainly with the representatives of its own "world-economy", i.e. the countriesrepresentatives of "the USA's/the UK's group" are Iceland's main partners in international trade, migration, and air logistics. A kind of sub-"world-economy" is formed which can be referred to as a Northern-Atlantic one;

2) these social and economic interactions (with the representatives of its own "world-economy") mainly draw Iceland's sustainable territory development in their direction, and, as the trends of their sustainable development are negative or stagnate (see Appendix), Iceland's trend of competitiveness is also drawn after them, especially after the USA and Spain;

3) rather infrequent (low intensity) social and economic interactions with the countries - representatives of other "worlds-economies" either do not influence significantly Iceland's sustainable territory development (the case with Brazil) or influence in the opposite way (the case with China), i.e. the growth in China means the fall in Iceland.

Therefore, the practical efficiency of recommendation of Human Development Report 2013 to interact more actively with other "worlds-economies" is not so far proved in social and economic reality - at least, in the case with Iceland as a typical highly-developed capitalist country.

\section{References}

Anselin, L. 1988. Spatial Econometrics, Methods and Models. Boston: Kluwer Academic Publishing. Available on the Internet: http://www.csiss.org/GISPopSci/workshops/2009/UCSB/readings/Anselin1988.pdf

Anselin, L. 2003. Spatial Externalities, Spatial Multipliers and Spatial Econometrics, International Regional Science Review, 26: 153-166. Available on the Internet: http://web.pdx.edu/ crkl/SEAUG/papers/Anselin_IRSR_2003.pdf

Azamatova, R., Shadova, Z.,Shorova, B. 2017. Economic security and international relations in the European Union, Journal of Security and Sustainability Issues, 6(4): 711-718. http://doi.org/10.9770/jssi.2017.6.4(15)

Barry, F. 2014. Diversifying External Linkages: The Exercise of Irish Economic Sovereignty in Long-Term Perspective, IIIS Discussion Paper, No. 448. Available on the Internet: https://www.tcd.ie/iiis/documents/discussion/pdfs/iiisdp448.pdf

Benediktsson, K., Karlsdottir, A. 2011. Iceland: Crisis and Regional Development. Thanks for All the Fish? European Urban and Regional Studies, 18(2): 228-235. http://dx.doi.org/10.1177/0969776411402282

Boronenko, V. 2007. Klasteru pieeja region attīstībai zināšanu ekonomikā [Cluster Approach for Regional Development in Knowledge Economy].Daugavpils: DU publishing house „Saule” 
Boronenko, V. 2009. The Role of Clusters in the Development of Regional Competitiveness. Jelgava: LUA Faculty of Economics. Available on the Internet: http://llufb.llu.lv/conference/economic_science_rural/2009/ESRD_19-2009.pdf

Boronenko, V. 2014. Role of Clusters in Regional Competitiveness. LAMBERT Academic Publishing. Available on the Internet: https://click-knighki.ga/54868-the-role-of-clusters-in-regional-competitiveness/

Boronenko, V., Drezgic, S. 2014. Economic Determinants of Territory Competitiveness and Development Sustainability, Social Sciences Bulletin, 19(2): 44-67 Available on the Internet: https://du.lv/wpcontent/uploads/2016/05/DU_Ekonomika_2014_2015.pdf

Boronenko, V., Lavrinenko, O. 2016. Role of Social and Economic Interactionsin Territory Development of Iceland,Gecomplexity Discussion Paper series. Available on the Internet: http://econpapers.repec.org/paper/cstwpaper/

Boronenko, V., Mensikovs, V., Lonska, J., Ohotina, A. 2015. Rethinking Territory Development in the Global World Based on the Pluralistic Paradigm, Proceedings of the 10th International Scientific Conference "Economic Integrations, Competition and Cooperation", 211-228.

Boyer, R. 2009. Srednevekovaja Islandija [Medieval Iceland]. Moscow: Veche.

Braudel, F. 1967. Civilization and Capitalism, 15th-18th Centuries. Translated by Sian Reynolds S. 1979. 3 vols. Berkeley: University of California Press. Available on the Internet:

https://www.goodreads.com/book/show/762098.Civilization_and_Capitalism_15th_18th_Century_Vol_2

Cihelkova, E., Nguyen, H., Wozhniakova, M., Strakova, R. 2017. The EU-China comprehensive strategic partnership in context of EU general concept of the "Strategic Partnership", Journal of Security and Sustainability Issues, 6(4): 729-744. https://doi.org/10.9770/jssi.2017.6.4(17)

Delyagin, M. 2015. World is Broken: Russia and China Have to Create a New One. Available on the Internet $\underline{\text { http://svpressa.ru/politic/article/121275/?rss_mirtesen=1 }}$

Dubrova T. A. Statisticheskie metody prognozirovaniya [Statistical Methods of Fore- casting]. Moscow, Yuniti-Dana Publ., 2003.

Efremenko, D.V., Meleshkina, E.Y. 2014. Teoriya modernizaciyi o putyah socialyno-ekonomicheskogo razvitiya [Theory of Modernization about Paths of Social and Economic Development], Sotsiologicheskie issledovaniya [Sociological Researches], 6: 3-12. Available on the Internet: http://socis.isras.ru/files/File/2014/2014_6/Efremenko.pdf >

Eggertsson, T. 2006. On the Survival of Imperfect Institutions, Revista Análisis Económico, 21(2): 13-24. Available on the Internet: < https://www.researchgate.net/publication/5115446_On_the_Survival_of_Imperfect_Institutions

Elhorst, P. 2014.Spatial Econometrics: From Cross-Sectional Data to Spatial Panels. London: Springer. Available on the Internet: http://www.springer.com/gp/book/9783642403392

Fotheringham, A.S., Brunsdon, C., Charlton, M.E. 2000. Quantitative Geography: Perspectives on Spatial Data Analysis. Thousand Oaks, CA: Sage Publishers. Available on the Internet: https://risweb.st-andrews.ac.uk/portal/en/researchoutput/quantitative-geographyperspectives-on-spatial-data-analysis(c7b6913a-d7b0-4660-9538-11a117a5d0bf)/export.html

Global Footprint Network, Mediterranean Ecological Footprint Initiative. 2016. Why Are Resource Limits Now Undermining Economic Performance? Available on the Internet: http://www.footprintnetwork.org/images/article uploads/Med Policy Brief English.pdf

Hall, R. E., Jones, Ch. 1998. Why Do Some Countries Produce So Much More Output per Worker than Others? Quarterly Journal of Economics, 114: 83-116. Available on the Internet: https://web.stanford.edu/ chadj/HallJonesQJE.pdf

Johannesson, H. 2010a. Large Scale Activities in Small Scale Communities: Experiences from East Iceland. Available on the Internet: http://www.norden.org/sv/nordiska-ministerraadet/samarbetsministrarna-mr-sam/arktis/kalender/arctic-2013-changing-realities/tal-ochpresentationer/hjalti-johannesson-large-scale-activities-in-small-scale-communities

Johannesson, H. 2010b. Megaprojects in the Circumpolar North: Broadening the horizon, gaining insight, empowering local stakeholders - Social impacts: The case of the Kárahnjúkar power plant and Alcoa Fjarðál plant in Iceland. Available on the Internet: http://library.arcticportal.org/1487/1/Megaprojects_Circumpolar_North_Social-impacts_RHA_appendix_Aug-10.pdf 
The International Journal
ENTREPRENEURSHIP AND SUSTAINABILITY ISSUES

ISSN 2345-0282 (online) http://jssidoi.org/jesi/

2018 Volume 5 Number 3 (March)

http://doi.org/10.9770/jesi.2018.5.3(1)

Johannesson, H., Heidarsson, J.D., Sigurbjarnarson, V. 2010. Social Impact of an Aluminium Plant in East Iceland 2002-2008: Main

Findings.Available on the Internet: http://www.smv.gl/Baggrundsrapporter/Social_impacts_East_Iceland_vs_Maniitsoq_June_2010.pdf

Kirkby, D. 2012. Tiger Economies: The Evolution of Economic Rhetoric, Discussion Papers of the Consultancy Africa Intelligence. Available on the Internet: <http://www.consultancyafrica.com/index.php?option=com_content\&view=article\&id=1085:tiger-economiesthe-evolution-of-econom ic-rhetoric-\&catid=58:asia-dimension-discussion-papers \&Itemid=264/>.

Kiva, A.V. 2014. Mechty i realiyi strani BRIK: [Countries of the BRIK: Dreams and Reality], Sociologicheskie issledovaniya [Sociological Researches], 9: 39-49. Available on the Internet: http://socis.isras.ru/files/File/2014/2014 9/39-49 Kiva.pdf

Kuenne, R.E. 1963. Spatial Economics. In: Kuenne, R.E. ed. The Theory of General Economic Equilibrium, Princeton University Press: 395-454.

Lahart, J., Barta, P., Batson, A. 2008. New Limits to Growth Revive Malthusian Fears, The Wall Street Journal. Available on the Internet: http://www.wsj.com/articles/SB120613138379155707

Lavrinenko, O., Ohotina, A., Amosova, J., Teivāns-Treinovskis, J. 2017. Intercompany networks of the cross-border region (LatviaLithuania-Belarus), Journal of Security and Sustainability Issues, 7(1): 39-54. https://doi.org/10.9770/jssi.2017.7.1(4)

LeSage, J., Pace, R.K. 2009. Introduction to Spatial Econometrics. Taylor \& Francis Group, LLC. Available on the Internet: http://enistat.lecture.ub.ac.id/files/2013/02/James_LeSage_Robert_Kelley_Pace-

Introduction_to_Spatial_Econometrics_Statistics_A_Series_of_Textbooks_and_Monographs-Chapman_and_Hall_CRC2009.pdf

LeSage, J.P. 1999. The Theory and Practice of Spatial Econometrics. Available on the Internet: http://www.spatialeconometrics.com/html/sbook.pdf

Logason, T. 2012. Power Elites \&Corruption. Reykjavik: Eva Joly Institute.

Lonska, J. 2014. Assessment of Territorial State of Development in Latvian Regions. Daugavpils: Daugavpils University. Available on the Internet : https://du.lv/wp-content/uploads/2015/12/Jelenas_Lonskas_kopsavilkums_save.pdf

Lonska, J., Boronenko, V. 2012.Correlation of Objective and Subjective Territorial Development Indices in the World, European Integration Studies, 6. Available on the Internet: http://www.eis.ktu.lt/index.php/EIS/article/view/1468

Lopez-Claros, A. ed. 2006. The Global Competitiveness Report 2006-2007. Geneva: World Economic Forum. Available on the Internet: http://www3.weforum.org/docs/WEF_GlobalCompetitivenessReport_2006-07.pdf

Lopez-Claros, A., Porter, M.E., Schwab, K. eds. 2005. The Global Competitiveness Report 2005-2006: Policies Underpinning Rising Prosperity. Geneva: World Economic Forum. Available on the Internet: http://www3.weforum.org/docs/WEF_GlobalCompetitivenessReport_2006-07.pdf

Lopez-Claros, A., Schwab, K. eds. 2007. The Global Competitiveness Report 2007-2008.Geneva: World Economic Forum. Available on the Internet: http://www3.weforum.org/docs/WEF_GlobalCompetitivenessReport_2008-09.pdf

Meadows, D.H., Meadows, D.L., Randers, J., Behrens III, W.W. 1972. The Limits to Growth: A Report to the Club of Rome. Washington: Potomac Associates. Available on the Internet: http://collections.dartmouth.edu/published-derivatives/meadows/pdf/meadows_ltg-001.pdf

Meadows, D. H., Randers, J., Meadows, D. L. 2004. Limits to Growth: The 30-Year Update. Chelsea Green Publishing Company, White River Junction VT. Available on the Internet: http://www.peakoilindia.org/wp-content/uploads/2013/10/Limits-to-Growth-updated.pdf

Mensikovs, V., Lavrinenko, O., Sinica, L., Simakhova, A. 2017. Network capital phenomenon and its possibilities under the influence of development of information and communication technologies, Journal of Security and Sustainability Issues, 6(4): 585-604. https://doi.org/10.9770/jssi.2017.6.4(5)

Pakholok, O. 2013. The Idea of Healthy Lifestyle and Its Transformation into Health-Oriented Lifestyle in Contemporary Society,SAGE Open, July-September: 1-10. Available on the Internet: http://journals.sagepub.com/doi/abs/10.1177/2158244013500281

Schwab, K. ed. 2008. The Global Competitiveness Report 2008-2009. Geneva: World Economic Forum. Available on the Internet: https://www.weforum.org/reports/global-competitiveness-report-2008-2009 
Schwab, K. ed. 2009. The Global Competitiveness Report 2009-2010. Geneva: World Economic Forum. Available on the Internet: http://www3.weforum.org/docs/WEF_GlobalCompetitivenessReport_2009-10.pdf

Schwab, K. ed. 2010. The Global Competitiveness Report 2010-2011. Geneva: World Economic Forum. Available on the Internet: http://www3.weforum.org/docs/WEF_GlobalCompetitivenessReport_2010-11.pdf

Schwab, K. ed. 2011. The Global Competitiveness Report 2011-2012. Geneva: World Economic Forum. Available on the Internet: <http://www3.weforum.org/docs/WEF_GCR_Report_2011-12.pdf>

Schwab, K. ed. 2012. The Global Competitiveness Report 2012-2013. Geneva: World Economic Forum. Available on the Internet: http://www3.weforum.org/docs/WEF_GlobalCompetitivenessReport_2012-13.pdf

Schwab, K. ed. 2013. The Global Competitiveness Report 2013-2014. Geneva: World Economic Forum. Available on the Internet: http://www3.weforum.org/docs/WEF_GlobalCompetitivenessReport_2013-14.pdf

Schwab, K. ed. 2014. The Global Competitiveness Report 2014-2015. Geneva: World Economic Forum. Available on the Internet: http://www3.weforum.org/docs/WEF_GlobalCompetitivenessReport_2014-15.pdf

Schwab, K. ed. 2015. The Global Competitiveness Report 2015-2016. Geneva: World Economic Forum. Available on the Internet: http://www3.weforum.org/docs/gcr/2015-2016/Global_Competitiveness_Report_2015-2016.pdf

Sen, A. 1983. Development: Which Way Now? Economic Journal, Royal Economic Society, 372(93): 742-762.

Stankevics, A., Ignatjeva, S., Mensikovs, V. 2014. Higher Education's Contribution to Economic Performance and Innovativeness in Latvia: Exploratory Research, Economic Annals, 202(59): 7-41.

Statistics Iceland. 2011. Trade in Goods in 2010, Statistical Series 2011/1.

Statistics Iceland. 2016a. Exports by Countries, Years and Months 1988-2014, Exports by countries April 2015, External trade: Exports in Goods. Available on the Internet: https://www.wto.org/english/res_e/statis_e/wts2016_e/wts2016_e.pdf

Statistics Iceland. 2016b. Imports by Countries, Years and Months 1988-2014, Imports by Countries April 2015, External trade: Imports in Goods. Available on the Internet: https://www.wto.org/english/res e/statis e/wts2016 e/wts2016 e.pdf

Statistics Iceland. 2016c. External Migration by Sex, Countries and Citizenship 1986-2014: Emigration, Migration: External Migration. Available on the Internet: https://www.wto.org/english/res_e/statis_e/wts2016_e/wts2016_e.pdf

Statistics Iceland. 2016d. External Migration by Sex, Countries and Citizenship 1986-2014: Immigration, Migration: External Migration. Available on the Internet: https://www.wto.org/english/res e/statis e/wts2016 e/wts2016 e.pdf

Tahvonen, O. 1998.Economic Sustainability and Scarcity of Natural Resources: A Brief Historical Review. Available on the Internet: http://www.rff.org/files/sharepoint/WorkImages/Download/RFF-IB-00-tahvonen.pdf

Takayama, T., Judge, G.G. 1964. Equilibrium among Spatially Separated Markets: A Reformulation, Econometrica, 32 : $510-524$. Available on the Internet: https://www.jstor.org/stable/1910175

Thirlwall, A.P. 2011. Economics of Development (9 ${ }^{\text {th }}$ ed.).Palgrave Macmillan.

Todaro, M.P., Smith, S.C. 2011. Economic Development (1 $11^{\text {th }}$ Edition). New York: Prentice Hall.

Tvaronavičienè, M. 2018. Towards efficient policy making: forecasts of vulnerability to external global threats, Journal of Security and Sustainability Issues 7(3): http://doi.org/10.9770/jssi.2018.7.3(18)

ulHaq, M. ed. 1995. Human Development Report 1995. United Nations Development Programme. New York: Oxford University Press. Available on the Internet: http://hdr.undp.org/sites/default/files/reports/256/hdr 1995 en complete nostats.pdf

UNDP. 2013. Human Development Report 2013. The Rise of the South: Human Progress in a Diverse World. Available on the Internet: http://hdr.undp.org/en/2013-report 
The International Journal

ENTREPRENEURSHIP AND SUSTAINABILITY ISSUES

ISSN 2345-0282 (online) http://jssidoi.org/jesi/

2018 Volume 5 Number 3 (March)

http://doi.org/10.9770/jesi.2018.5.3(1)

Wade, R.H., Sigurgeirsdottir, S. 2012. Iceland's Rise, Fall, Stabilization and Beyond, Cambridge Journal of Economics, 36: 127-144. Available on the Internet: http://inctpped.ie.ufrj.br/spiderweb/pdf_1/8_RW_icelands_rise_2012.pdf

World Bank. 2016. Energy Use ( $k g$ of oil equivalent per capita). Available on the Internet: http://data.worldbank.org/indicator/EG.USE.PCAP.KG.OE

Zoega, G. 2013. The West as an (Almost) Exclusive Club, Working Paper series of the Institute of Economic Studies, W13:08, Reykjavik: University of Iceland. Available on the Internet: http://www.ioes.hi.is/sites/hhi.hi.is/files/W-series/2013/WP1308.pdf

\section{Annex}

Growth lines of Iceland's partners created by the regressive curve estimation method, the Global Competitiveness Index, 2005-2015.

Fig. 5. Growth line of Canada created by the regressive curve estimation method, the Global Competitiveness Index, 2005-2015

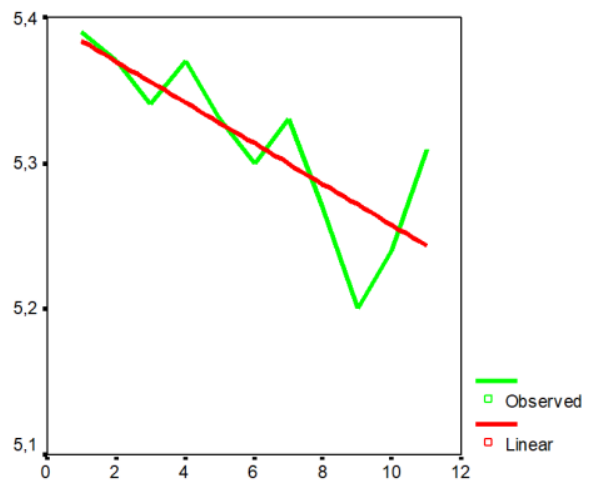

Fig.7. Growth line of Denmark created by the regressive curve estimation method, the Global Competitiveness Index, 2005-2015

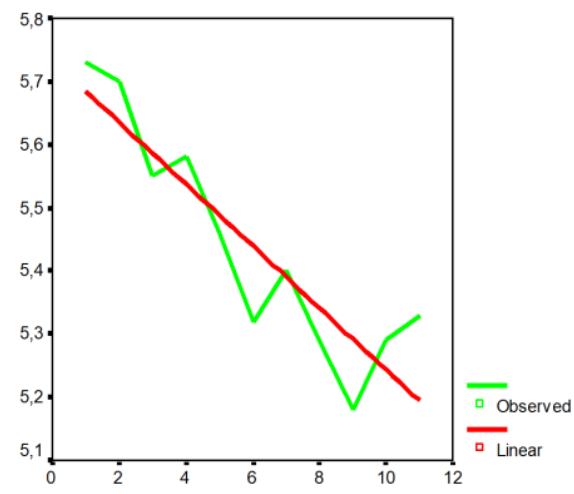

Fig. 6. Growth line of the USA created by the regressive curve estimation method, the Global Competitiveness Index, 2005-2015

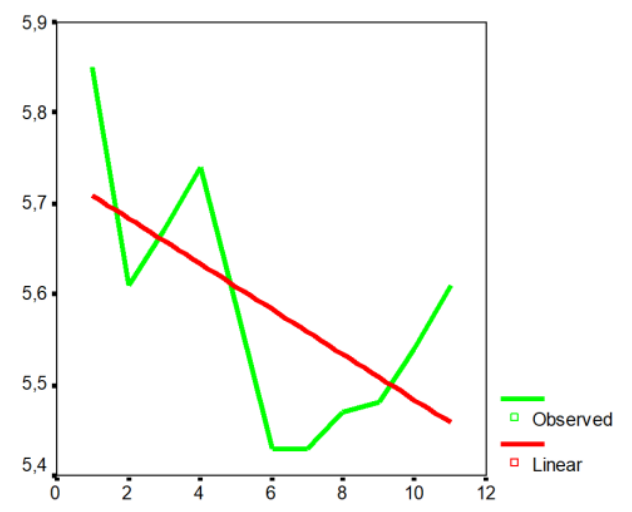

Fig.8. Growth line of Sweden created by the regressive curve estimation method, the Global Competitiveness Index, 2005-2015

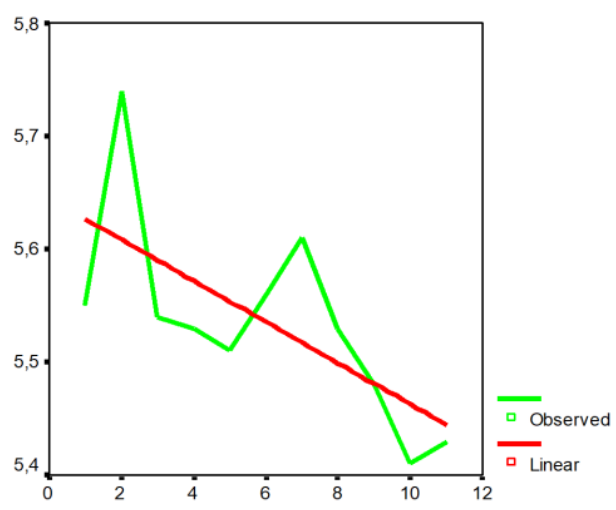


Source: elaborated by the authors using SPSS software on the basis of Lopez-Claros et al., 2005; Lopez-Claros, 2006; Lopez-Claros, Schwab, 2007; Schwab, 2008, 2009, 2010, 2011, 2012, 2013, 2014, 2015.

Fig. 9. Growth line of Finland created by the regressive curve estimation method, the Global Competitiveness Index, 2005-2015

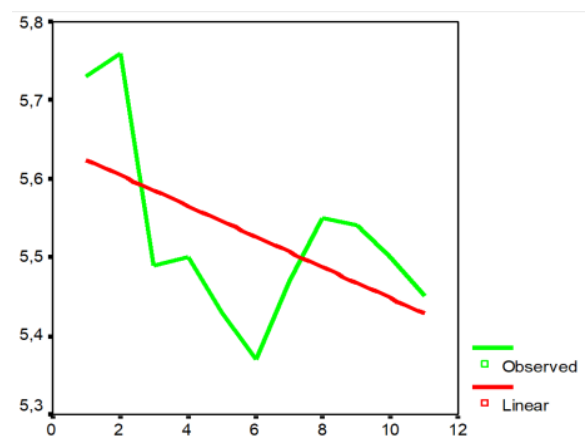

Fig.11.Growth line of Spain created by the regressive curve estimation method, the Global Competitiveness Index, 2005-2015

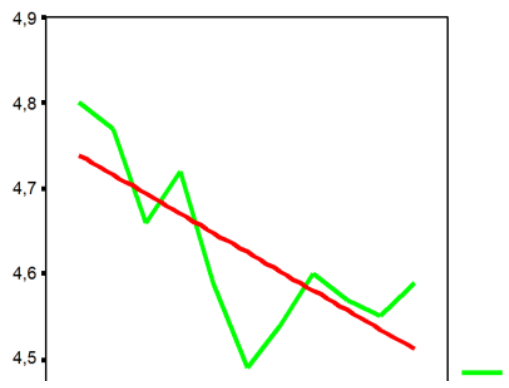

Fig. 13. Growth line of the UK created by the regressive curve estimation method, the Global Competitiveness Index, 2005-2015

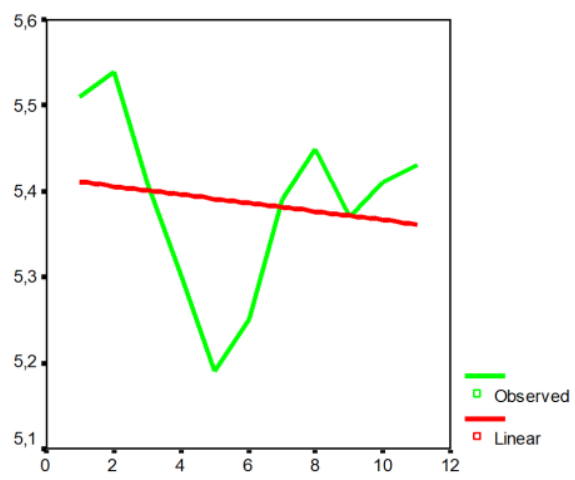

Fig. 10. Growth line of France created by the regressive curve estimation method, the Global Competitiveness Index, 2005-2015

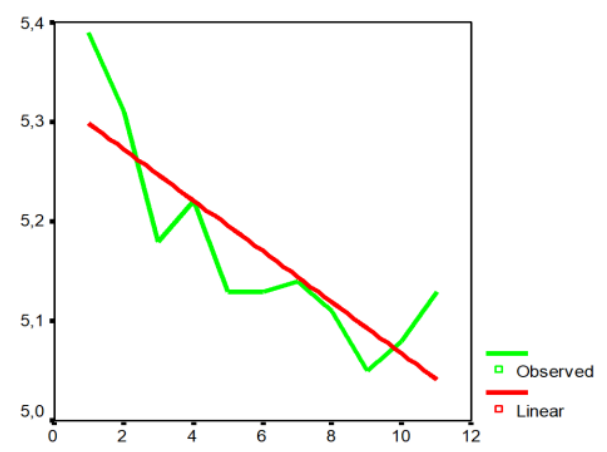

Fig.12. Growth line of Germany created by the regressive curve estimation method, the Global Competitiveness Index, 2005-2015

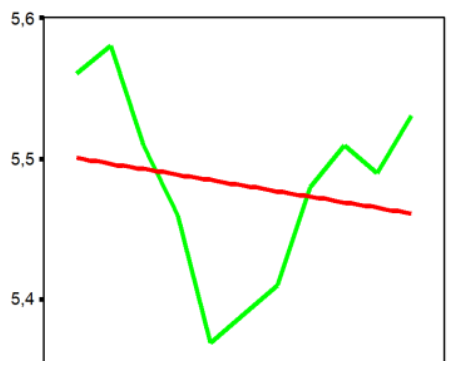

Fig. 14. Growth line of Belgium created by the regressive curve estimation method, the Global Competitiveness Index, 2005-2015

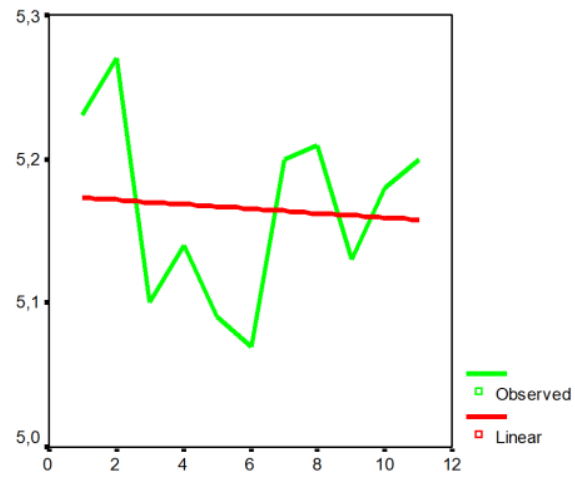


The International Journal

ENTREPRENEURSHIP AND SUSTAINABILITY ISSUES

ISSN 2345-0282 (online) http://jssidoi.org/jesi/

2018 Volume 5 Number 3 (March)

http://doi.org/10.9770/jesi.2018.5.3(1)

Fig.15. Growth line of Lithuania created by the regressive curve estimation method, the Global Competitiveness Index, 2005-2015

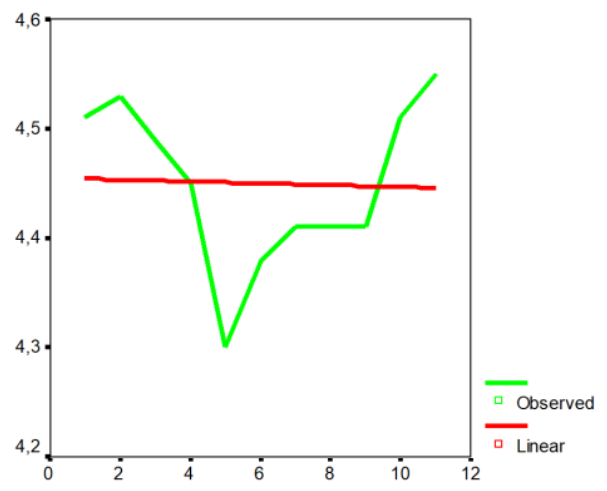

Fig. 16. Growth line of Netherlands created by the regressive curve estimation method, the Global Competitiveness Index, 2005-2015

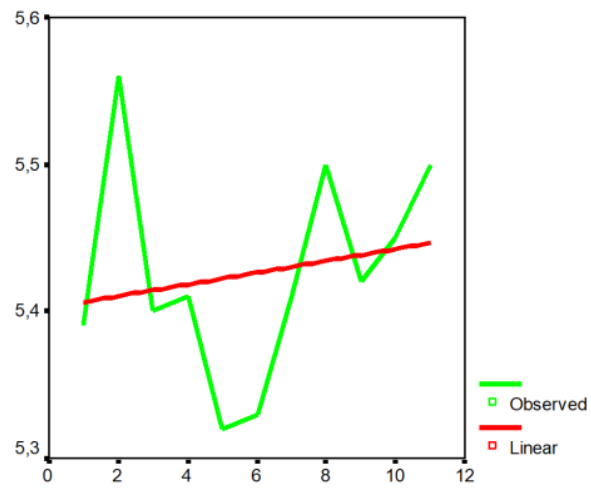

Source: elaborated by the authors using SPSS software on the basis of Lopez-Claros et al., 2005; LopezClaros, 2006; Lopez-Claros, Schwab, 2007; Schwab, 2008, 2009, 2010, 2011, 2012, 2013, 2014, 2015.

Fig. 17. Growth line of Norway created by the regressive curve estimation method, the Global Competitiveness Index, 2005-2015

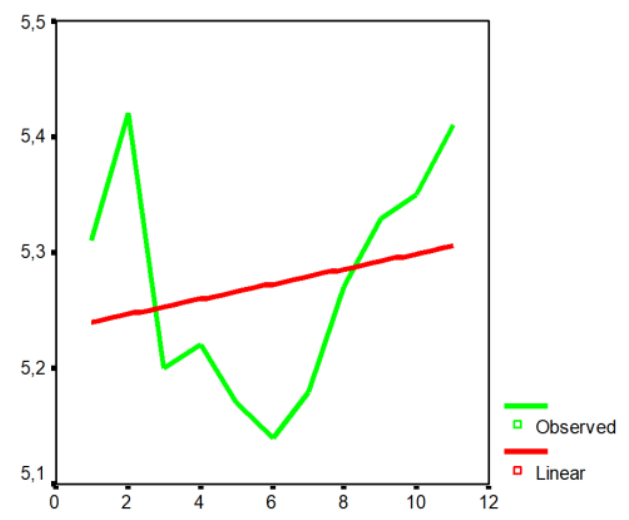

Fig. 19. Growth line of Brazil created by the regressive curve estimation method, the Global Competitiveness Index, 2005-2015

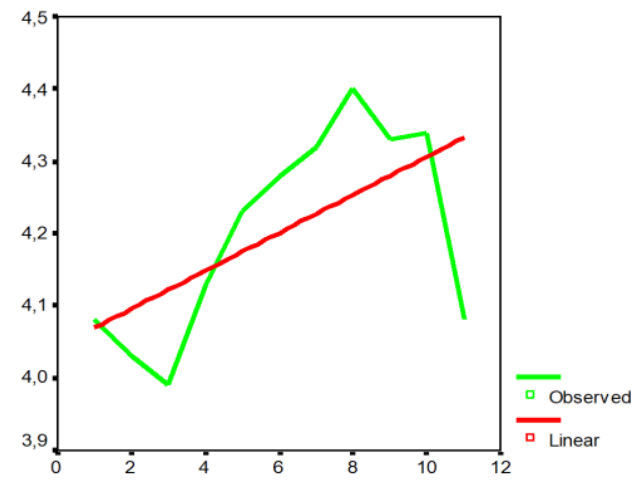

Fig. 18. Growth line of Poland created by the regressive curve estimation method, the Global Competitiveness Index, 2005-2015

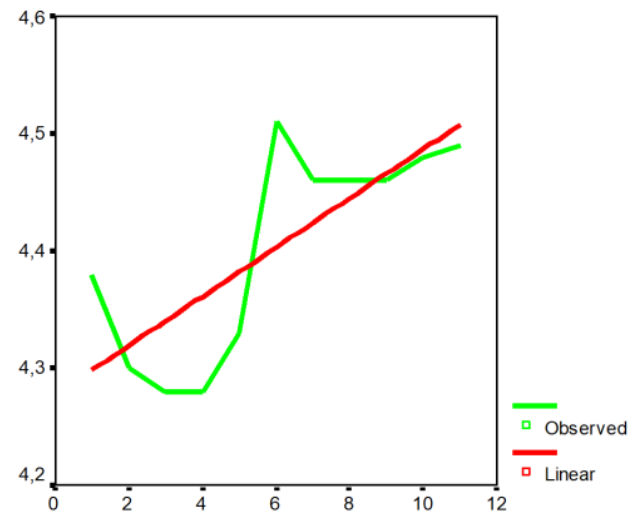

Fig. 20. Growth line of China created by the regressive curve estimation method, the Global Competitiveness Index, 2005-2015

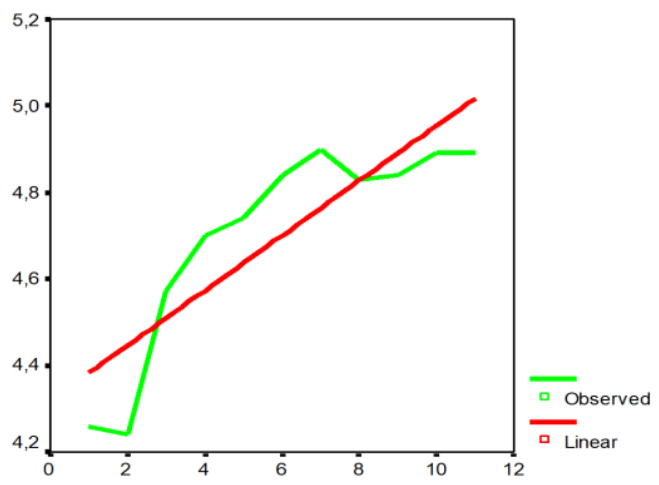


Source: elaborated by the authors using SPSS software on the basis of Lopez-Claros et al., 2005; Lopez-

Claros, 2006; Lopez-Claros, Schwab, 2007; Schwab, 2008, 2009, 2010, 2011, 2012, 2013, 2014, 2015.

\section{Aknowledgements}

The research leading to these results has received funding from the European Union Seventh Framework Programme (FP7 2007-2013) under grant agreement No. 291823 Marie Curie FP7-PEOPLE-2011-COFUND (The new International Fellowship Mobility Programme for Experienced Researchers in Croatia-NEWFELPRO). This article has been worked out as a part of the project „Rethinking Territory Development in Global Comparative Researches (Rethink Development)” which has received funding through NEWFELPRO project under grant agreement No. 10

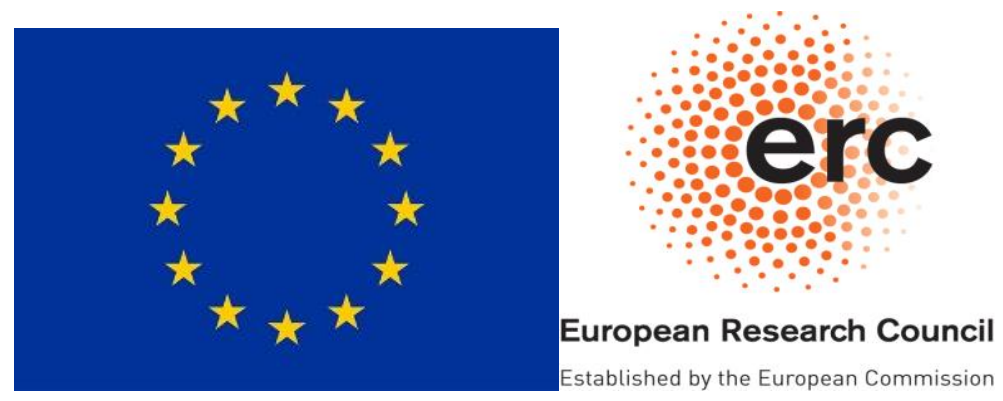


The International Journal

ENTREPRENEURSHIP AND SUSTAINABILITY ISSUES

ISSN 2345-0282 (online) http://jssidoi.org/jesi/

2018 Volume 5 Number 3 (March)

http://doi.org/10.9770/jesi.2018.5.3(1)

Vera KOMAROVA is Dr. oec, Leading researcher at the Institute of Humanities and Social Sciences of Daugavpils University (Latvia). She has status of the external expert of the COST Association (Brussel). Her research interests: regional economics, sustainable territory development.

ORCID ID: https://orcid.org/0000-0002-9829-622X

Jelena LONSKA is Dr. oec., Researcher at the Business and Society Process Research Center of Rezekne Academy of Technologies (Latvia), as well as associate professor at the Faculty of Economics and Management. She has status of the expert of the Latvian Council of Science in the field of economics. Her research interests: regional economics, sustainable development, measuring state of development of countries.

ORCID ID: https://orcid.org/0000-0002-8140-4810

Olga LAVRINENKO is Dr. oec, Leading researcher at the Institute of Humanities and Social Sciences of Daugavpils University, (Latvia). She has status of experts of the Latvian Council of Science in the field of economics. Her research interests: regional economics, sustainable economic development.

ORCID ID: https://orcid.org/0000-0001-7383-3749

Vladimir MENSHIKOV is Dr. sc. soc., Professor at Daugavpils University. His research interests: sociology of security; regional development; capital theory. He has status of the expert of the Latvian Council of Science in the fields of economics and sociology. He is a head of the Centre of Social Researches in Daugavpils University (Latvia).

ORCID ID: https://orcid.org/0000-0001-9988-8588

Register for an ORCID ID:

https://orcid.org/register

Copyright (C) 2018 by author(s) and VsI Entrepreneurship and Sustainability Center

This work is licensed under the Creative Commons Attribution International License (CC BY).

http://creativecommons.org/licenses/by/4.0/

CC) (i) Open Access 